\title{
Personality trait differences across types of entrepreneurs: a systematic literature review
}

\author{
Florentine U. Salmony ${ }^{1}$ D . Dominik K. Kanbach ${ }^{1}$
}

Received: 18 June 2020 / Accepted: 17 April 2021 / Published online: 8 May 2021

(C) The Author(s) 2021

\begin{abstract}
The personality traits that define entrepreneurs have been of significant interest to academic research for several decades. However, previous studies have used vastly different definitions of the term "entrepreneur", meaning their subjects have ranged from rural farmers to tech-industry start-up founders. Consequently, most research has investigated disparate sub-types of entrepreneurs, which may not allow for inferences to be made regarding the general entrepreneurial population. Despite this, studies have frequently extrapolated results from narrow sub-types to entrepreneurs in general. This variation in entrepreneur samples reduces the comparability of empirical studies and calls into question the reviews that pool results without systematic differentiation between sub-types. The present study offers a novel account by differentiating between the definitions of "entrepreneur" used in studies on entrepreneurs' personality traits. We conduct a systematic literature review across 95 studies from 1985 to 2020 . We uncover three main themes across the previous studies. First, previous research applied a wide range of definitions of the term "entrepreneur". Second, we identify several inconsistent findings across studies, which may at least partially be due to the use of heterogeneous entrepreneur samples. Third, the few studies that distinguished between various types of entrepreneurs revealed differences between them. Our systematic differentiation between entrepreneur subtypes and our research integration offer a novel perspective that has, to date, been widely neglected in academic research. Future research should use clearly defined entrepreneurial samples and conduct more systematic investigations into the differences between entrepreneur sub-types.
\end{abstract}

Keywords Entrepreneur personality $\cdot$ Entrepreneur traits $\cdot$ Entrepreneur characteristics $\cdot$ Literature review $\cdot$ Entrepreneur types

Mathematics Subject Classification 00-A-99 · 91-02 · 91-C-99

Florentine U. Salmony

florentine.salmony@hhl.de

1 Dr. Ing. h.c. F. Porsche AG Chair of Strategic Management and Digital Entrepreneurship, HHL

Leipzig Graduate School of Management, Leipzig, Germany 
JEL Classification L26 · D91 · J24

\section{Introduction}

Small businesses form a vital part of the global economy and constitute the majority of ventures in most regions (Mazzarol and Reboud 2020). By creating new small businesses, entrepreneurs effect economic growth and development in their communities (Stel et al. 2005; Bosma et al. 2018). To promote entrepreneurial activity and provide support to small businesses, an understanding of what characterizes those who found and manage such businesses is required (Shane 2003). As such, academics and policymakers alike are interested in determining how entrepreneurs' personality traits differ from those of the general population.

Before we can characterize entrepreneurs in terms of their personality traits, we must first define the term "entrepreneur". While entrepreneurship research has expanded significantly, it remains fragmented in its approaches and definitions (Ferreira et al. 2019). Consequently, entrepreneur classifications span a vast number of definitions (Chell et al. 1991) that rarely overlap (Wickham 2006). Accordingly, studies have based their research on a variety of samples of subjects that can all technically be classified as entrepreneurs. In truth, however, these samples vary substantially. For example, some studies on entrepreneurial personality traits examine founders of technology-based enterprises (Roberts 1989), some define entrepreneurs as local farmers (Mubarak et al. 2019) and others survey nursing students as potential entrepreneurs (Ispir et al. 2019). While these exemplary subjects can all be classified as "entrepreneurs" in the broadest sense, as disparate entrepreneur sub-types they are likely more different than similar. At the same time, mandating a single unified definition of "entrepreneur" would limit the insights gained from different samples. Instead, a clear differentiation between entrepreneurial sub-types should be made to provide concrete insights into the traits of various types of entrepreneurs.

Several previous literature reviews (e.g. Jennings and Zeithaml 1983; Johnson 1990; Stewart and Roth 2001, 2007; Collins et al. 2004; Zhao and Seibert 2006; Zhao et al. 2010; Brandstätter 2011; Kerr et al. 2018; Newman et al. 2019) have summarized insights into entrepreneurial personality traits that have been made across academic research. However, to our knowledge, none have systematically and fully differentiated between the types of entrepreneurs sampled in their included studies as part of their main review. ${ }^{1}$ Further, several literature reviews have incorporated studies that themselves differed in their use of the term "entrepreneur". Thus, different entrepreneurial samples were used in the individual studies and integrated without further differentiation in the reviews. It is, however, questionable whether the results of the studies referenced in the reviews are directly comparable if they used different entrepreneur sub-types. Beyond this, some reviews have included studies that tested samples of non-entrepreneurs but did not highlight this in their review. For example, students with entrepreneurial interest are frequently

1 Few reviews, e.g., Kerr et al. (2018), include a differentiation by entrepreneurial type in their appendix. 
used as samples in studies investigating entrepreneurial personalities, and these results are often included in reviews, despite these students not yet being practicing entrepreneurs. Last, as every review has set out to characterize entrepreneurs based on marginally different or nonexistent entrepreneur definitions, their sets of included studies have differed. Taken together, while these literature reviews offer important insights into the personality traits of entrepreneurs in the broadest sense, they do not enable us to make inferences about different sub-types of entrepreneurs.

The aim of this study is to systematically examine previous research on entrepreneurs' personality traits while actively differentiating between the types of entrepreneurs analyzed in each study. We integrate information from 95 papers to explore whether inconsistencies in their findings can be explained by definitional variation and to examine whether there are personality differences across entrepreneur subtypes. However, we do not aim to divide the previous research by strict definitional categories of entrepreneurs. Instead, we make inferences from the entrepreneur subtype examined and outline potential gaps in the literature where differentiation in entrepreneur types has yet to be made clear. To do this, we apply the guidelines offered by Kraus et al. (2020) to conduct a systematic literature review (Tranfield et al. 2003) of studies on entrepreneur characteristics while focusing on what their findings reveal about different sub-types of entrepreneurs.

This study has several benefits for academic research on entrepreneurs' personality traits. It offers novel insights into more specific entrepreneur categories by actively differentiating many entrepreneur types and evaluating the variation in entrepreneur samples. Furthermore, this literature review helps to disentangle which personality traits are associated with entrepreneurial interest, venture creation, and entrepreneurial success, depending on the type of entrepreneur sampled. For example, the personality factors that facilitate venture success may vary by entrepreneur or company type. From a hypothetical perspective, the success of a second-generation microenterprise may rely on Conscientiousness while that of an aggressively growth-oriented, early-stage start-up may depend on Innovativeness and Risk-taking propensity.

We pursue three main research objectives throughout this review. First, we investigate whether previous research on entrepreneurial personalities has varied in its definition of the term "entrepreneur" in the way we assumed. Second, we examine whether there are inconsistent findings in previous research. Without being able to infer causality from a literature review, we propose that one potential explanation for such inconsistencies is the use of different definitions of entrepreneur. Third, we note the personality differences between entrepreneur sub-types in the few studies that differentiate between them.

\section{Systematic literature review methodology}

This study used the systematic literature review methodology from Tranfield et al. (2003). We first set out to gain an overview of the field and to define our research objectives in an inductive pre-analysis. As the number of personality traits for investigation was potentially infinite, the choice must inherently be limited. A selection 
of traits was obtained through an inductive pre-analysis of the commonly measured personality traits in research on entrepreneurs: (1) the Big Five (Zhao and Seibert 2006; Zhao et al. 2010; Kerr et al. 2018), (2) Need for Achievement (nAch; Rauch and Frese 2007; Stewart and Roth 2007), (3) Innovativeness (Kerr et al. 2018), (4) Entrepreneurial Self-Efficacy (ESE; Miao et al. 2017; Newman et al. 2019), (5) Locus of Control (LOC; Jennings and Zeithaml 1983), and (6) Risk attitudes (Stewart and Roth 2001).

Based on this pre-analysis, these six most common personality traits formed the main component of our search string ("Appendix 1"), which we iterated in feedback loops among our working group. As recommended by Kraus et al. (2020) for entrepreneurship literature reviews, we restricted our search to online databases and journal articles, and excluded books, conference papers and conference proceedings.

We applied our search string and received an initial sample of 1453 publications from the Web of Science (1367), JSTOR (19) and ScienceDirect (67) databases. A set of 34 papers was excluded because the papers were not retrievable in full text to us. The quality of the remaining papers was reviewed based on the corresponding journal rankings. For this, we applied the conversion table of academic journal rankings (Kraus et al. 2020), and the journals with at least a C-rating in VHB JQ3 or the equivalent in $\mathrm{ABS}(\geq 2)$ or JCR IF $(\geq 1.5)$ were included. This quality gate led to the exclusion of further 799 papers. After careful consideration, 4 papers that were lower than the defined quality threshold were reincluded because of their importance to our research question. We thoroughly checked for methodological or sampling concerns in the four papers, took note of any potential drawbacks we observed but did not note any of major significance. Next, all abstracts were reviewed, and 529 papers were excluded because they did not contribute to answering our research objectives, as outlined in the introduction.

Our final sample consisted of 95 papers, ${ }^{2}$ of which 14 were literature reviews or meta-analyses, and 81 were empirical studies. We checked whether the 14 literature reviews outlined papers similar to the 81 empirical studies identified in our literature review and found a comprehensive overlap. This showed us that we had likely not missed or erroneously excluded any relevant papers. Our final sample was transferred into an Excel data extraction form that we used to analyze the information by personality trait and entrepreneur sub-type investigated.

This review aims to provide novel insights by clearly differentiating between the definitions of the term "entrepreneur" used in studies on entrepreneurial personality traits. As already outlined, we examined six different personality traits ${ }^{3}$ across the six sections of our review. The distribution of the included literature reviews and meta-analyses and empirical studies across the six personality traits is outlined in Fig. 1. Please note that the sum of the analyzed empirical studies and literature

\footnotetext{
2 The papers analyzed in our systematic literature review can be found on the Open Science Framework: osf.io.

3 The personality traits were (1) the Big Five, (2) Need for Achievement (nAch), (3) Innovativeness, (4) Entrepreneurial Self-efficacy (ESE), (5) Locus of Control (LOC), and (6) Risk attitudes.
} 


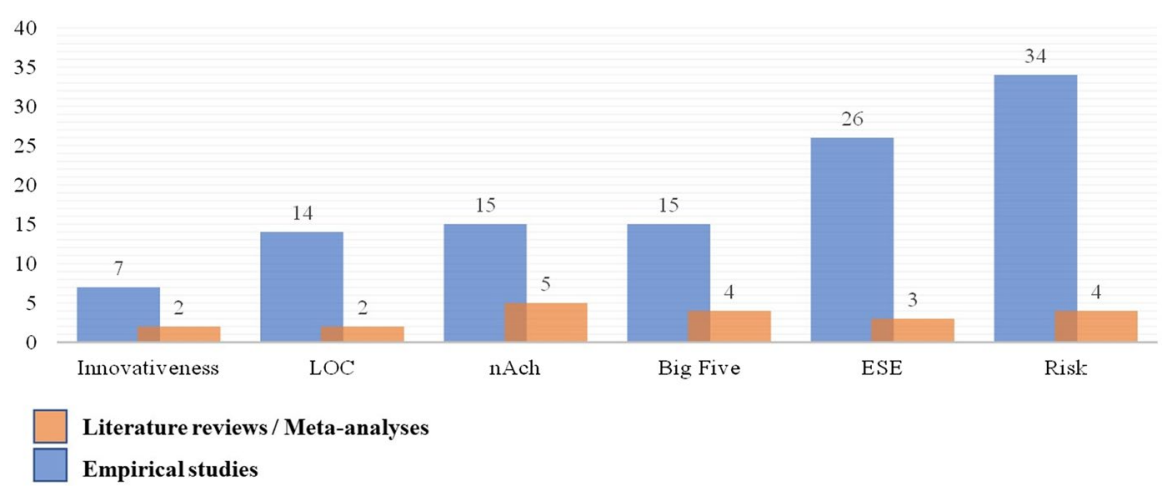

Fig. 1 Distribution of personality trait focus across analyzed papers

reviews was 95, but several of the studies and reviews elucidated more than one personality trait.

Our approach for the remainder of our literature review is the following. After the introduction and methodology sections, we outline our insights for each of the six personality traits and, in a second part, summarize our findings per entrepreneur sub-type. Here, we show personality differences and similarities between individual entrepreneur sub-types. Finally, we discuss our findings.

\section{Integrated insights per personality trait}

The papers summarized in our literature review covered all six personality traits: the Big Five, Need for Achievement, Innovativeness, Entrepreneurial Self-Efficacy, Locus of Control, and Risk attitudes.

As outlined in the introduction, previous literature reviews and meta-analyses on entrepreneur personalities have frequently relied on different definitions of the term "entrepreneur". This has resulted in empirical studies with different entrepreneurial samples being included in reviews without further differentiation and consequently the comparison of potentially incomparable samples. Similarly, empirical studies on entrepreneur personalities have rarely shared the same definition of "entrepreneur". In our literature review, we first set out to retrieve the various definitions of "entrepreneur" used in previous research. An exemplary selection of the definitions of entrepreneur samples in previous research is shown in Table 1.

In the following sections, we will conduct an in-depth review of the findings from our literature review. We first review entrepreneur definition differences for the six personality traits examined, and in a later part, we draw general inferences and characterize a selection of entrepreneur sub-types. 


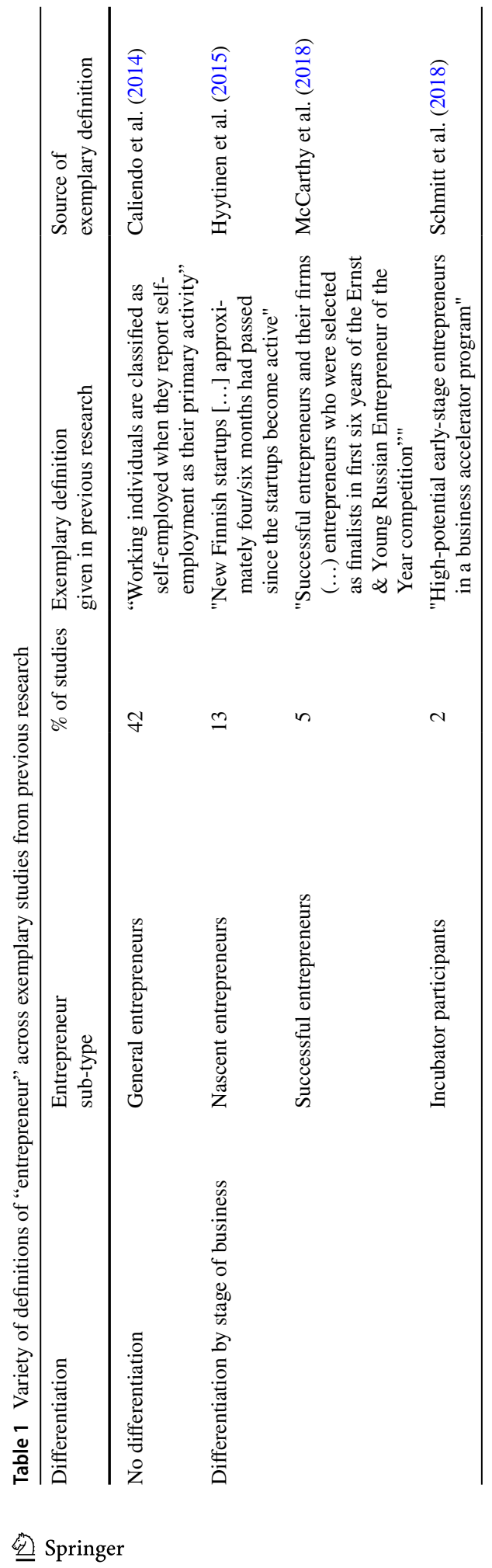




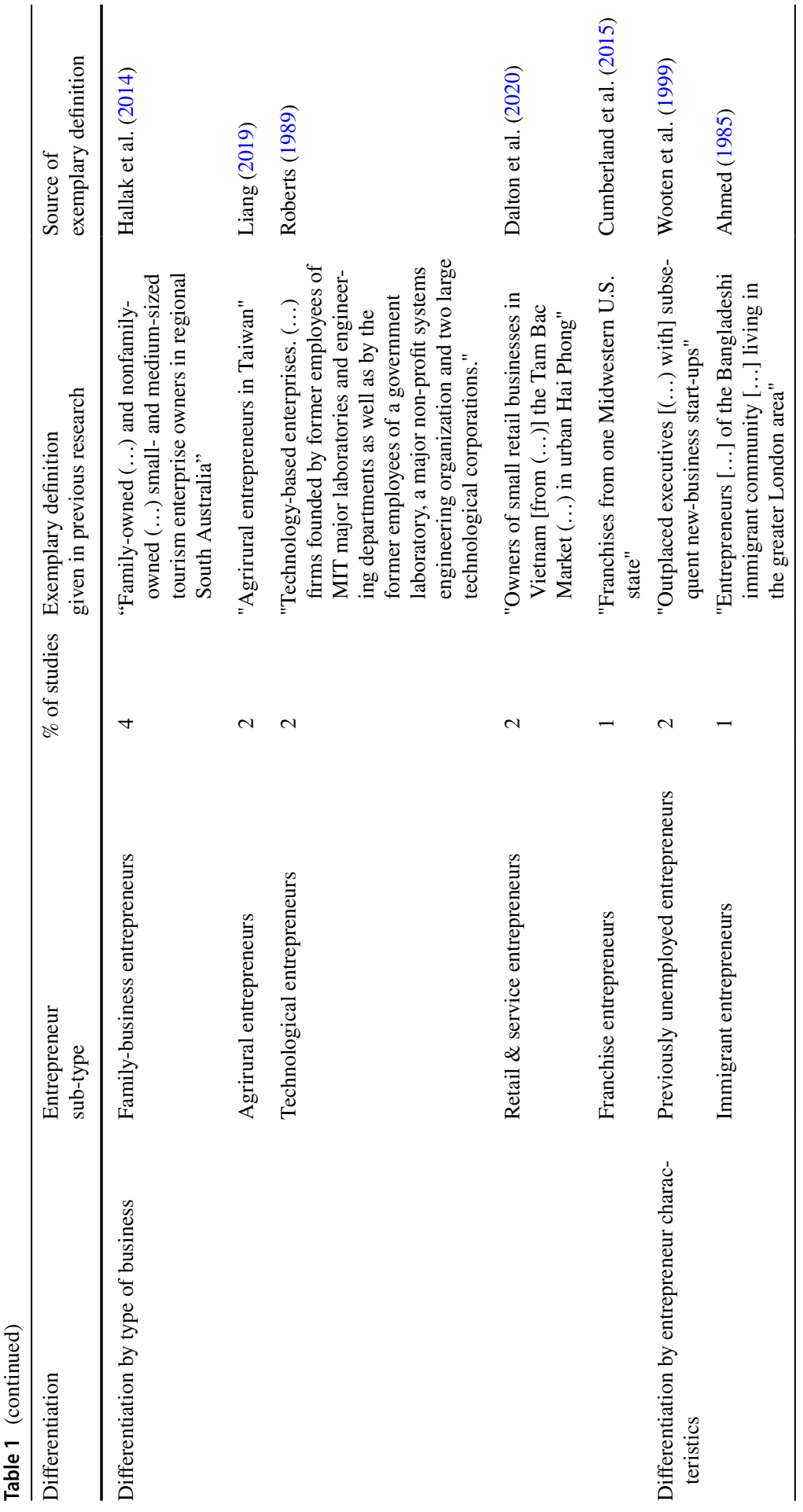




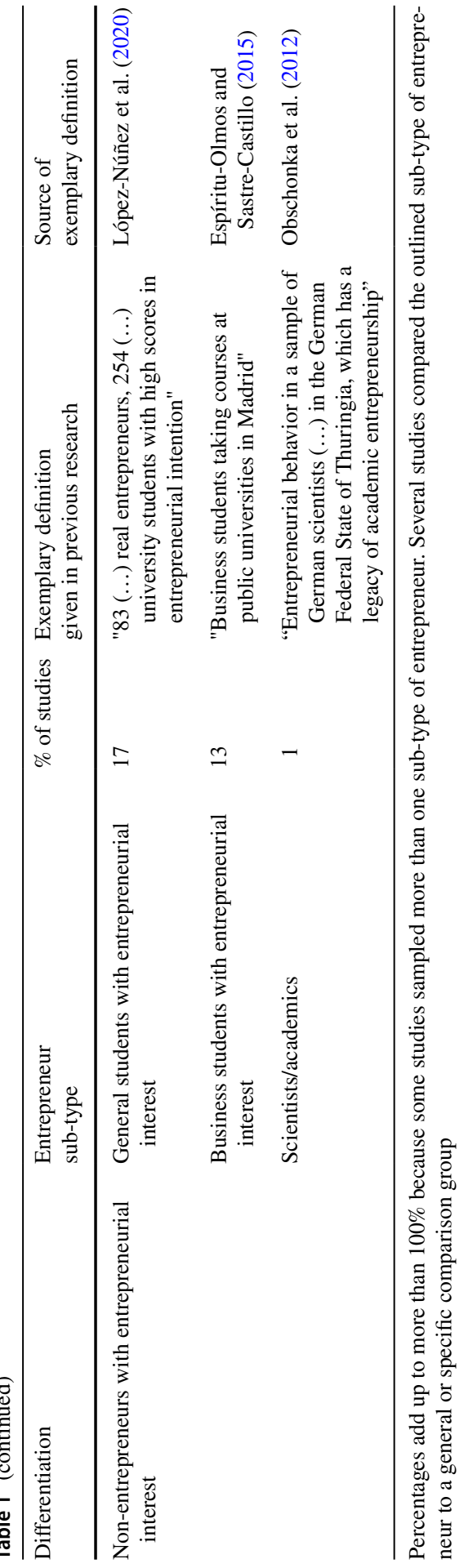




\subsection{The Big Five}

\subsubsection{Preface: concept introduction}

The "Big Five" (Goldberg 1990; McCrae and John 1992) is a common classification system of personality traits. It is a replicable and robust methodology for grouping thousands of potential personality descriptors (Ostendorf and Angleitner 1994) while maintaining generalizability across samples and methodologies (John and Srivastava 1999). As the name states, the Big Five consists of five categories: Extraversion, Agreeableness, Conscientiousness, Neuroticism and Openness to Experience.

The Big Five taxonomy of personality traits dates back more than 70 years (Fiske 1949). Originally, little academic consensus around which personality traits were part of it resulted in different researchers applying a variety of personality traits in their research. Consequently, this methodological variance led to contradictory findings. In the 1980s, this lack of methodological consensus resulted in a widespread view that the relationship between entrepreneurial behavior and personality traits was overrated and should not be investigated further. The re-emergence of the Big Five taxonomy in the 1990s (Costa and McCrae 1992a, b) enabled researchers to conduct more systematic investigations into the relationship between personality and entrepreneurial activity. Since then, academic interest in entrepreneurs' personality traits has resurfaced, with the Big Five at the center of the discussion.

\subsubsection{Integrated insights from our review}

From our review, we drew two main insights regarding the use of various samples in previous research on the Big Five traits of entrepreneurs. These were on the use of different entrepreneur sub-types across research to date, and second, on the extensive use of non-entrepreneurial samples in previous research on entrepreneurial personalities.

First, we observed that different entrepreneur sub-types were tested as samples when the Big Five personality traits were investigated. Simultaneously, we observed some discrepancies in the findings, regarding Extraversion and Agreeableness in particular. For example, regarding Agreeableness, we observed a breadth of entrepreneurial definitions and simultaneously different findings regarding personality traits. Despite this, few studies directly compared different entrepreneur sub-types in the Big Five. One example is Antoncic et al. (2015) who sampled non-entrepreneurs and entrepreneurs along the founding process. While the practicing entrepreneurs were lower in Agreeableness than the non-entrepreneurs, potential entrepreneurs with entrepreneurial interest—but who had not already founded-were the lowest in Agreeableness of all. Without being able to infer causality, this may offer a hypothesis why some studies who use non-founding students with entrepreneurial interest as a proxy for actual entrepreneurs observe no correlation between Agreeableness and entrepreneurial intent (Chan et al. 2015; Mei et al. 2017). A further example is Yang and Ai (2019) who showed differences in all five of the Big Five personality dimensions between self-employed and agrirural entrepreneurs. Whilst these 
observations are merely exemplary, they indicate that previous research has applied a span of entrepreneurial definitions and that results differ depending on the subtype analyzed. This demonstrates that outcome variation can co-occur with definitional differences. Despite these definition-dependent discrepancies, few empirical studies tested them through direct comparisons of entrepreneur sub-types.

Although we cannot infer causality, it is possible that the variability in these findings was due to the differences in the entrepreneur types sampled in the individual studies. It is important to differentiate between entrepreneurial types, as it may explain the existing discrepancies. Future research differentiating more between different entrepreneur types will likely reveal that the Big Five personality traits vary by business form, environment, and entrepreneur type. For example, we hypothesize that Agreeableness is more important in larger organizational settings, which require a high level of coordination with peers, than in self-employment settings. Similarly, we hypothesize that Extraversion is more important for entrepreneurs in settings with considerable interpersonal exchange with many stakeholders than for those engaging in individual labor.

As our second main insight, we noted that non-entrepreneurs were frequently tested in previous entrepreneurship personality research. While the use of these nonentrepreneurial groups is valid to investigate entrepreneurial interest, the findings may not be directly transferable toward the personality traits of practicing entrepreneurs. Although interest may be an important determinant of later behavior (Ajzen 1991), personality differences may exist between those who are entrepreneurially interested and those who act on this interest by founding a venture. Outside of the entrepreneurial domain, research has sometimes observed merely week correlations between interest and behavior that are below practical significance (Rhodes and Dickau 2012). Because of this, it becomes particularly important to clearly differentiate between entrepreneurially interested samples and practicing entrepreneurs. In our review, we observed that several studies examined the Big Five across two types of non-entrepreneurial samples. First, the largest group of studies on entrepreneurial interest involved college or university students (e.g. Chan et al. 2015; Mei et al. 2017), likely due to the accessibility of student samples. It is, however, questionable whether students with entrepreneurial interest can truly shed light on the personalities of practicing entrepreneurs, as they have not yet founded a business and have entrepreneurial interest at most. Second, scientists and academics were sometimes used as entrepreneur proxies (Obschonka et al. 2012). While these insights about entrepreneurial activity in a specific subset of non-entrepreneurs are highly valuable to research per se, they cannot offer the full depth of insights about practicing entrepreneurs in general, due to the samples' inherent focus on entrepreneurial interest.

\subsubsection{Summary: the Big Five}

Our study supports the findings of earlier reviews regarding entrepreneurs' Big Five traits (high Openness to Experience, high Conscientiousness, low Neuroticism), including the mixed results regarding Agreeableness and Extraversion. To our knowledge, previous reviews have not systematically differentiated between entrepreneur sub-types in their main analyses. In addition, empirical studies have applied 
vastly different definitions in selecting their entrepreneurial samples and simultaneously show somewhat inconsistent results. When we classified the studies in our review based on their definition of the term "entrepreneur," the results became more consistent. We cannot make any inferences about causality from our review. However, the differences in entrepreneurial definitions constitute a promising hypothesis regarding the previous inconsistencies, which we encourage future research to pursue. Furthermore, we observed that previous research tended to rely upon non-entrepreneurial samples to investigate the personality traits of entrepreneurs. We encourage future research toward differentiation in entrepreneur types and toward the more widespread use of samples of actually practicing entrepreneurs.

\subsection{Need for Achievement}

\subsubsection{Preface: concept introduction}

Need for Achievement (nAch; Murray 1938; McClelland et al. 1953) is a multidimensional construct encompassing individual motivations to achieve goals within an environmental setting (Cassidy and Lynn 1989; Ward 1997). McClelland (1961) first hypothesized that high nAch predisposes individuals toward an entrepreneurial orientation, as those individuals obtain a higher degree of achievement satisfaction from entrepreneurial activities. The construct of nAch relates to various elements of the Big Five and does so to a different extent depending on whether intrinsic or extrinsic nAch is being examined (Hart et al. 2007).

\subsubsection{Integrated insights from our review}

Few of the previous studies on nAch actively differentiated between different types of entrepreneurs. Consequently, the reviews that exist on the topic can only differentiate between very few categories of entrepreneur sub-types, for example between entrepreneurs with either growth- or income-orientation. A meta-analysis by Stewart and Roth (2007) argued that inconsistencies in the findings of previous studies on nAch were likely due to different entrepreneur samples. While some studies found entrepreneurs to have higher nAch than managers (Begley and Boyd 1987), others observed no difference (Cromie and Johns 1983). Stewart and Roth (2007) claimed that these outcome differences likely stemmed from variation in the definitions of the term "entrepreneur" and in the entrepreneur samples. They concluded that (1) entrepreneurs in general had moderately higher nAch than managers; (2) entrepreneurs who founded a business rather than inheriting one had higher nAch; and (3) entrepreneurs with a growth-orientation had higher nAch than those who were income-oriented. This is in line with Stewart et al. (1999), who compared corporate managers and entrepreneurs who were differentiated as growth-oriented and strategically planning or as interested in providing family income. The growthoriented entrepreneurs had significantly higher nAch than the corporate managers and family income-oriented entrepreneurs. Interestingly, the family income-oriented 
entrepreneurs were more similar to the corporate managers than to the growth-oriented entrepreneurs.

However, it should be noted that all but one of the studies in the Stewart and Roth (2007) review date back to 1999 or earlier. Entrepreneur types and business orientations are likely to have changed since then, especially given the creation of entirely new sectors and business models. Furthermore, while they noted some differences between entrepreneur groups across the studies (e.g., owners or founders), other differences were not investigated despite some of the reviewed studies making more detailed differentiations between entrepreneur types. For example, some of the reviewed studies specifically investigated nAch in small, early-stage companies (Utsch et al. 1999) or companies in the manufacturing or service industry (Bellu et al. 1990). Despite this, neither the stage nor the industry of the companies was differentiated. Nevertheless, Stewart and Roth (2007) demonstrated the benefit of distinguishing between entrepreneur types, as nAch differences can be observed. Evidently, there is a gap in the existing literature regarding the effect of nAch on entrepreneurial performance.

Second, some of the studies on nAch investigated the personality traits of nonentrepreneurs, by examining entrepreneurial intention in individuals who had not yet founded a business. For example, Zeffane (2013) demonstrated that nAch was the most important determinant of self-assessed entrepreneurial potential of business students in the UAE. Other studies compared these pre-founding non-entrepreneurs to individuals who were practicing entrepreneurs in the stricter sense. For example, Taormina and Lao (2007) compared the effects of nAch on Chinese respondents who were interested in starting a business, were planning to start a business, or had already established a business. The respondents who had already started a business had higher nAch than those who were planning to do so, who themselves had higher nAch than the respondents who were not interested in starting a business. These findings show that there are significant nAch differences between individuals who are practicing entrepreneurs and non-entrepreneur individuals with entrepreneurial interest. Because of this, caution should be taken when purely non-entrepreneurial samples with entrepreneurial interest are tested to investigate entrepreneurial personalities in general.

\subsubsection{Summary: need for achievement}

Stewart and Roth (2007) confirmed the benefit of differentiating entrepreneur types by observing nAch differences not only between entrepreneurs and managers but also between founding and inheriting entrepreneurs and between growth-oriented and income-oriented entrepreneurs. However, the research has yet to thoroughly differentiate entrepreneur types. Overall, there have been few studies on nAch to date that systematically differentiate between entrepreneur sub-types, for example, regarding growth- or income-orientation. Future research with systematic differentiation of additional sub-types would likely find that nAch varies by orientation or business type. For example, entrepreneurs with high nAch may be more willing to take Risks and prefer a growth-oriented setting, while those with low nAch may prefer a safe but steady environment. Furthermore, the limited research on entrepreneur 
sub-types currently focuses on niche groups. This trend makes it difficult to draw general inferences about entrepreneurs. Future studies on nAch should clearly differentiate the entrepreneur sub-types in their samples.

\subsection{Innovativeness}

\subsubsection{Preface: concept introduction}

Entrepreneurial Innovativeness is one of the first psychological traits to have received academic attention. An early hypothesis posited that entrepreneurs and managers would differ most in terms of their inclination toward innovation (Schumpeter 1934). Accordingly, Innovativeness is a personality trait that is often a central component of entrepreneurial orientation (Kraus et al. 2019) and activity (Mueller and Thomas 2001). While definitions of Innovativeness vary across the academic literature (Hurt et al. 1977), we adopt the following definition: "interindividual differences in how people react to [...] new things" (Goldsmith and Foxall 2003). While Innovativeness at the individual and company levels is linked (Strobl et al. 2018), in this review, we investigated Innovativeness exclusively at the individual level rather than at the team or company level.

Innovativeness can be measured either temporally, i.e., how quickly an individual adopts innovations, or operationally, i.e., how frequently an individual chooses innovative behavior (Midgley and Dowling 1978). There are multiple measures of Innovativeness as a personality trait, none of which are consistently applied in academic research. Examples include the Adaption-Innovation Inventory (Kirton 1976) and the Jackson Personality Inventory (Jackson 1994). Alternatively, Innovativeness can be measured as a behavioral outcome through, for example, the Innovative Behavior Inventory (Lukes et al. 2009; Lukes and Stephan 2017).

\subsubsection{Integrated insights from our review}

As Kerr et al. (2018) poignantly noted, "the biographies of Steve Jobs alone likely outnumber the formal academic studies" on entrepreneurial Innovativeness. Furthermore, to our knowledge, no published meta-analysis or literature review has exclusively focused on the relationship between Innovativeness and entrepreneurial interests or activities. The reviews that have analyzed Innovation and entrepreneurs (Brem 2011; Schmitz et al. 2017) have mainly done so in terms of innovative outcomes, innovative processes or organization-wide Innovation. Innovativeness as an entrepreneurial personality trait, however, can occasionally be found as a sub-topic within general meta-analyses or literature reviews. For example, as part of their meta-analysis, Rauch and Frese (2007) investigated the predictive validity of Innovativeness, among other personality traits, on entrepreneurial activity and success. The studies they included defined entrepreneurs as active or interested independent business owners or active managers. Innovativeness was significantly and positively correlated with business creation and business success. However, there were no further entrepreneur-type differentiations in the individual studies. 
Our literature review of empirical studies observed a general link between Innovativeness and entrepreneurial interest (Altinay et al. 2012) and venture performance or survival (Hyytinen et al. 2015), with a negative association in the latter. However, few studies have performed any kind of entrepreneur-type differentiation. One positive example is Lukes (2013), who investigated differences in innovative behavior between entrepreneurs and managers through samples drawn from Germany, the Czech Republic, Italy, and Switzerland. Lukes (2013) measured innovative behavior with the Innovative Behavior Inventory (Lukes et al. 2009) in computer-assisted telephone interviews. The study differentiated between (1) entrepreneurs with employees, (2) self-employed individuals without employees, (3) employed managers, and (4) regular employees. Unlike most other studies, it excluded students, unemployed people, homemakers, and pensioners from the sample. It found that the entrepreneurs with employees displayed the most innovative behavior. The employees without subordinates displayed the least innovative behavior except on a subscale of "involving others", where self-employed individuals displayed the least innovative behavior. The entrepreneurs and the self-employed individuals generated new ideas more often than the managers, who had new ideas more often than the employees. The employees searched for new ideas less often than the entrepreneurs, self-employed individuals, and managers. The entrepreneurs were the most active in terms of implementing novel ideas. Interestingly, no differences were found between the entrepreneurs across the four countries from which the sample was taken.

\subsubsection{Summary: innovativeness}

Despite entrepreneurial Innovativeness receiving early academic attention, it remains largely uninvestigated. In our review, we did not identify a single published meta-analysis or review dedicated solely to entrepreneurial Innovativeness. Few individual studies on this topic actively differentiated entrepreneur sub-types. Those that did (e.g. Lukes 2013), however, consequently identified personality differences between the sub-types. While the number of studies differentiating Innovativeness between entrepreneur sub-types is insufficient to draw any conclusions, these initial observations encourage further differentiation in future research.

\subsection{Entrepreneurial self-efficacy}

\subsubsection{Preface: concept introduction}

Self-Efficacy is a person's perception of or belief in their "ability to influence events that affect their lives" (Bandura 2010). It can change over the course of a lifetime, for example, through dedicated interventions (Bachmann et al. 2020). Self-Efficacy is most commonly measured through a 22-item multidimensional measure (Chen et al. 1998). Several other measures of Self-Efficacy have been developed with a varying number of subdimensions (Lee and Bobko 1994; Mone 1994; Maurer and Pierce 1998; Chen et al. 2001). The breadth of measures alone suggests the potential 
for inconsistency across studies in the way in which Self-Efficacy is defined and measured (McGee et al. 2009; Drnovsek et al. 2010).

Self-Efficacy is widely agreed to be domain-specific (Schjoedt and Craig 2017) and to therefore vary depending on the context. Domain-specificity means that SelfEfficacy is a multidimensional construct that varies depending on the situation or context. For example, individuals can have high beliefs about their performance on a history test while having low beliefs about their ability on a biology test (Zimmerman 2000). Thus, Self-Efficacy can be higher in one domain and simultaneously lower in another. For this reason, narrowing the investigation specifically to Entrepreneurial Self-Efficacy (ESE), which is domain-specific to the entrepreneurial context, is necessary. ESE encompasses an individual's self-perceived ability regarding entrepreneurial outcomes (Chen et al. 1998; Newman et al. 2019). Using a general Self-Efficacy measure instead of a specific entrepreneurial measure may reverse the direction of the findings (Hyun et al. 2019).

\subsubsection{Integrated insights from our review}

In our literature review, we again identified the two previously mentioned themes: previous research used largely different entrepreneurial sub-types when investigating ESE, and prior studies often relied on non-entrepreneur samples, such as students, when investigating ESE as an entrepreneurial personality trait.

First, regarding the use of different entrepreneur sub-types, a literature review by Newman et al. (2019) reported mixed results, with some studies showing a link between ESE and venture creation (Hechavarria et al. 2012; Hopp and Stephan 2012) and others not (Kolvereid and Isaksen 2006; Dalborg et al. 2015). Without being able to infer causality, a potential explanation for the mixed results may be that the examined studies used different definitions of the term "entrepreneur" and thus employed different sample types. We positively noted that Newman et al. (2019) differentiated between some of the entrepreneur types in the samples in the studies they examined. For example, regarding entrepreneurial intentions, they separated studies with samples of students from those with samples of working people. However, the differentiation could have extended further, for example toward growthand income-oriented entrepreneurs, which some of the analyzed studies investigate (Douglas 2013). Additionally, some of the studies relied on relatively narrow subsets of entrepreneurs, such as US homebrewers (Biraglia and Kadile 2017) or academics (Prodan and Drnovsek 2010), which can be differentiated from entrepreneurs in general.

Second, we again noted the widespread use of non-entrepreneur samples, such as students, in the previous literature. For example, the studies that compared entrepreneurs to non-entrepreneurs typically included only students in their samples (Culbertson et al. 2011). However, we noted that aside from individual studies (e.g. Chen et al. 1998), there appeared to be a lack of research on between-group comparisons, for example, between entrepreneurs and managers.

Regarding within-group studies, in our present literature review, we noted largely positive effects of ESE on entrepreneurial intention (Chen et al. 1998; Wilson et al. 2007; Laguna 2013) and firm performance (Luthans and Ibrayeva 
2006). In most of the studies we reviewed, entrepreneurial intention was the dependent variable. Moreover, the most frequently tested sample was again university students. Arguably, as noted previously, students are not actual entrepreneurs despite frequently being used as entrepreneurial proxies in the previous literature. The choice of this sample may suffice to explain why most of these studies examined entrepreneurial intentions: students will not yet have started a business, so their venture creation and entrepreneurial success are not yet measurable. Importantly, the validity of students as proxies for entrepreneurs is debatable. Some scholars believe there are drawbacks to using students as entrepreneurial proxies (McGee et al. 2009), while others call for differentiating between different types of students if sampling students is necessary (Chen et al. 1998; Hemmasi and Hoelscher 2005).

Due to the widespread use of student samples and the lack of differentiation between different entrepreneur types, it is difficult to draw conclusions about ESE in different types of entrepreneurs. Future research must more clearly differentiate between, for example, growth-oriented and income-oriented entrepreneurs. Since Self-Efficacy is related to factors such as Risk-taking (Llewellyn et al. 2008), high levels of ESE would likely be found in growth-oriented start-up entrepreneurs and not income-oriented family-business owners.

\subsubsection{Summary: entrepreneurial self-efficacy}

The previous reviews largely focused on the effect of ESE on entrepreneurial outcomes; thus, ESE differences across entrepreneur types have yet to be systemically analyzed. Most of the studies examined in this review focused on entrepreneurial intention as a dependent variable, largely because their samples consisted primarily of university students. The lack of diverse entrepreneurial samples currently limits the conclusions we can draw about individual entrepreneurial subtypes and allows few inferences toward entrepreneurs in general.

\subsection{Locus of control}

\subsubsection{Preface: concept introduction}

Locus of Control (LOC) is a construct that describes the extent to which individuals attribute outcomes to internal factors, such as effort and talent, or external factors, such as luck (Rotter 1966). LOC can be measured with a range of scales, including single-continuous-dimension scales ("Internalism-Externalism Scale"; Rotter 1966), bidimensional measures (Suárez-Álvarez et al. 2016), or multidimensional measures (Levenson 1973; Wallston et al. 1978; Lachman 1986). LOC appears to change over the course of a lifetime (Jennings and Zeithaml 1983). Should LOC have an impact on entrepreneurial activity and success, the ability to alter it would have interesting implications in several respects, such as entrepreneurial education. 


\subsubsection{Integrated insights from our review}

There have been several literature reviews on topics related to LOC, such as general LOC reviews (Lefcourt 1972; Reid 1985), reviews on LOC and organizational change (Kormanik and Rocco 2009), and reviews on LOC and health (Strudler Wallston and Wallston 1978). However, to our knowledge, there has been just one literature review dedicated solely to LOC and entrepreneurship (Jennings and Zeithaml 1983), which dates back nearly four decades. The authors reviewed studies from 1971 to 1979 on LOC in organizational and managerial settings and extrapolated their findings to entrepreneurship. They found that a higher internal LOC is associated with stronger entrepreneurial intention and activity (Pandey and Tewary 2011) and higher rates of entrepreneurial success (Hornaday and Aboud 1971; Andrisani and Nestel 1976; Anderson 1977). However, only one of the studies reviewed by Jennings and Zeithaml (1983) differentiated between entrepreneur types: an unpublished doctoral thesis by Scanlan (1979) separated growth-oriented entrepreneurs from income-oriented entrepreneurs. Here, no significant differences regarding $\mathrm{LOC}$ were found between the two types.

One potential drawback of the review by Jennings and Zeithaml (1983) is that all of the reported studies used the Rotter (1966) Internalism-Externalism Scale for measurement. This scale may be a problematic measure for entrepreneurship research, as it includes several dimensions that lie outside the realm of entrepreneurship, such as "political responsiveness". Therefore, the dimensions obtained using the scale may not be valid or useful predictors of entrepreneurial outcomes. Due to the various problems with the Rotter (1966) scale (Marsh and Richards 1986), multidimensional LOC measures may be more beneficial for future entrepreneurial LOC research.

In our present review, we observed that most of the studies on LOC did not differentiate between entrepreneur types. The few positive examples performing differentiations include Kerr et al. (2019), who compared entrepreneurs who self-identified as founders of their companies to both non-founding CEOs or owners and other types of employees. The founding entrepreneurs displayed the highest internal LOC, followed by the non-founding CEOs or owners, who themselves showed higher internal LOC than the employees.

Other studies involved a narrow sub-set of entrepreneurs. For example, Ahmed (1985) conducted a study on Bangladeshi entrepreneurs who had immigrated to the UK by comparing them with non-entrepreneurs; they similarly found that the entrepreneurs were higher in internal LOC than the non-entrepreneurs. Overall, the studies comparing different groups, such as entrepreneurs and managers, generally found that the entrepreneurs had higher internal LOC but did not conclusively differentiate between entrepreneur types.

The studies on within-group effects were mainly limited to student samples and thus typically examined the effects of LOC on entrepreneurial intention. Most of these studies found that higher internal LOC relates to stronger entrepreneurial intention. While the studies on practicing entrepreneurs were limited, the student samples spanned a variety of definitions and geographical locations. Examples of student samples used as entrepreneurial proxies included British hospitality students (Altinay et al. 2012), 
Iranian public university students (Karimi et al. 2017), or Romanian engineering and economics students (Voda and Florea 2019). Despite the breadth in samples of students with entrepreneurial interest, the studies typically found that internal LOC positively related to entrepreneurial intention.

The studies that went beyond student samples investigated venture creation, work satisfaction, and firm performance or growth. The usual link between LOC and entrepreneurial intention was found less often in the later stages of firm existence. For example, Caliendo and Kritikos (2008) found no effect of LOC on venture size in a sample of German business incubator participants. Similarly, in a sample of entrepreneurs belonging to firms with an age of at least three years and at least five employees, Imran et al. (2019) observed no direct link between internal LOC and firm performance. However, the effect of LOC on firm performance became positive and significant when mediated by entrepreneurial orientation. In different settings, LOC had a direct link with firm performance. For example, Lee and Tsang (2001) found that internal LOC had a positive impact on venture growth in a sample of Chinese entrepreneurs running SMEs in Singapore.

\subsubsection{Summary: locus of control}

To our knowledge, there has only been one literature review (Jennings and Zeithaml 1983) dedicated solely to entrepreneurial LOC. This review observed that higher internal LOC was associated with stronger entrepreneurial intention, higher degrees of entrepreneurial activity, and higher rates of entrepreneurial success. Our review confirmed the link between LOC and entrepreneurial intention. However, to our knowledge, most of the studies to date lacked a systematic differentiation between entrepreneur sub-types. Further, as with those on other personality traits, studies frequently limited their samples to students and thereby were inherently restricted to examining entrepreneurial intention.

Despite variation in the samples used when testing entrepreneurial intentions in students, previous studies have observed a positive relationship between internal LOC and entrepreneurial intentions. Regarding venture growth and performance, studies using heterogeneous samples of different types of entrepreneurs partially revealed mixed results. We cannot infer causality at this point, but a potential explanation may be that the outcome differences were due to definitional variation. Should future research systematically investigate LOC differences across entrepreneur types, it is likely that successful entrepreneurs will score higher on internal LOC, as external LOC is associated with a lesser ability to cope with challenges, better performance in stressful situations, greater innovation, and less Risk aversion (Jennings and Zeithaml 1983).

\subsection{Risk attitudes}

\subsubsection{Preface: concept introduction}

Risk attitudes describe individual decision-making preferences under uncertainty (Eeckhoudt and Schlesinger 2013). While Risk averse individuals prefer outcomes 
that are certain, Risk prone people prefer outcomes with higher levels of uncertainty. Risk attitudes are related to other personality traits, such as nAch (Meyer et al. 1961) and Self-Efficacy (Krueger and Dickson 1994). Most entrepreneurial studies have focused on Risk-taking propensity, which can be defined as an individual orientation toward taking Risks (Antoncic et al. 2018). Risk-taking propensity can change over the course of an individual's life, typically decreasing with age (Josef et al. 2016; Mata et al. 2016) and in response to exogenous or emotional shocks (SchildbergHörisch 2018).

\subsubsection{Integrated insights from our review}

The earliest investigation into entrepreneurial Risk as a personality trait (Knight 1921) established a model of competition and uncertainty. Knight (1921) hypothesized that entrepreneurs would be more inclined to take opportunities despite potential risks. Successful entrepreneurs would be those entrepreneurs with the most balanced Risk judgments. More recent research has confirmed many of these initial judgments. This widespread research into entrepreneurial Risk-taking propensity, however, typically has not sufficiently distinguished between different types of entrepreneurs.

Such differentiation between different sub-types of entrepreneurs is, however, important because there have been inconsistencies in the findings of previous studies. For example, in the comprehensive review by Kerr et al. (2018), some of the studies found no link between Risk propensity and performance (Zhao et al. 2010), some observed that higher Risk propensity related to lower performance (Hvide and Panos 2014), and some revealed that higher Risk propensity related to higher performance (Cucculelli and Ermini 2013). Interestingly, the entrepreneur samples in these studies were quite diverse. Zhao et al. (2010) based their findings on the following definition of entrepreneurs: individuals who are founders, owners, and managers of small businesses. The sample in the study conducted by Cucculelli and Ermini (2013) was drawn from 178 Italian manufacturing companies, and the entrepreneurs were defined as those individuals "in charge of major company decisions". Hvide and Panos (2014) tested a sample of common stock investors in terms of their sales and returns on assets in ventures they had founded. Using stock market participation as a high Risk-taking proxy, they compared this group of "entrepreneurs" to other entrepreneurs without stock market experience. These studies are merely exemplary but demonstrate that there is significant definitional variation.

Nevertheless, we made a positive observation that some studies did differentiate further between entrepreneur sub-types, primarily in terms of growth or income orientation. Growth- and opportunity-driven entrepreneurs typically exceeded incomeand necessity-oriented entrepreneurs in terms of Risk-taking propensity. For example, in a meta-analysis investigating differences in Risk-taking propensity between entrepreneurs and managers, Stewart and Roth (2001) differentiated between growth-oriented and income-oriented entrepreneurs. There was a larger difference between the Risk-taking propensity of the managers and the growth-oriented entrepreneurs than between the risk-taking propensity of the managers and the familyincome-oriented entrepreneurs. Thus, it appears that growth-oriented entrepreneurs 
are more inclined toward Risks than are income-oriented entrepreneurs. A further positive example is a study by Block et al. (2015), who differentiated between German early-stage, necessity-driven entrepreneurs and German early-stage, opportunity-driven entrepreneurs in an online survey. The entrepreneurs were assigned to sub-groups based on their self-classification of whether they had taken advantage of new business ventures or used entrepreneurship as their only employment option. Risk-taking propensity was measured both directly through self-perception and indirectly through a lottery-type question with a hypothetical investment. The opportunity-driven entrepreneurs were more willing to take Risks than the necessity-driven entrepreneurs.

We found some studies that differentiated between entrepreneur types while investigating the effects of Risk attitudes on venture creation. For example, Antoncic et al. (2018) examined the effect of Risk-taking propensity on entrepreneurial activity. Questionnaires were administered to 1414 university students across six countries. The students were classified as non-entrepreneurs $(24.4 \%)$, maybe-entrepreneurs $(52.6 \%)$, potential entrepreneurs (15.9\%), and practicing entrepreneurs $(7.1 \%)$. Across these groups, Risk-taking propensity was again associated with entrepreneurial activity in an inverted-U shape. Those individuals who ranked highest in Risk-taking propensity were likely to launch a venture in the next three years but had not yet done so. The practicing entrepreneurs exceeded only those individuals who might launch a venture at some point in the distant future and those who were not interested in launching one at any point. However, by relying on a student sample with only $7.1 \%$ practicing entrepreneurs, it must be noted that this study involved primarily on non-entrepreneurs and individuals in the pre-founding phases. We would encourage future research to build on these findings through a more detailed differentiation of venture phases of already practicing entrepreneurs.

Last, we would like to mention some observations on potential problems with the existing research on entrepreneurial Risk attitudes. There appears to be no agreed-upon measure of Risk attitudes, which makes comparisons between studies difficult, and perhaps impossible. The studies often used self-reported measures, to which entrepreneurs typically respond with overconfidence (Astebro et al. 2014) and, therefore, biased judgments. The studies may not be directly comparable to those using different Risk attitude measures (Palich and Bagby 1995). These measures include behavioral and quantitative proxies, such as stock market participation rates and R\&D expenditures. Furthermore, most of the studies tested general Risk attitudes instead of domain-specific entrepreneurial Risk-attitudes. These broad attitudes likely capture elements that are unrelated to entrepreneurial activity.

\subsubsection{Summary: risk attitudes}

In our review we took note of the mixed results regarding the relationship between Risk-taking propensity and entrepreneurial success. Studies have concluded that Risk-taking is negatively (Hvide and Panos 2014), positively (Cucculelli and Ermini 2013), or not related to entrepreneurial performance (Zhao et al. 2010). We demonstrated that different definitions of the term "entrepreneur" were used across these studies. Thus, disparate entrepreneurial samples were used. 


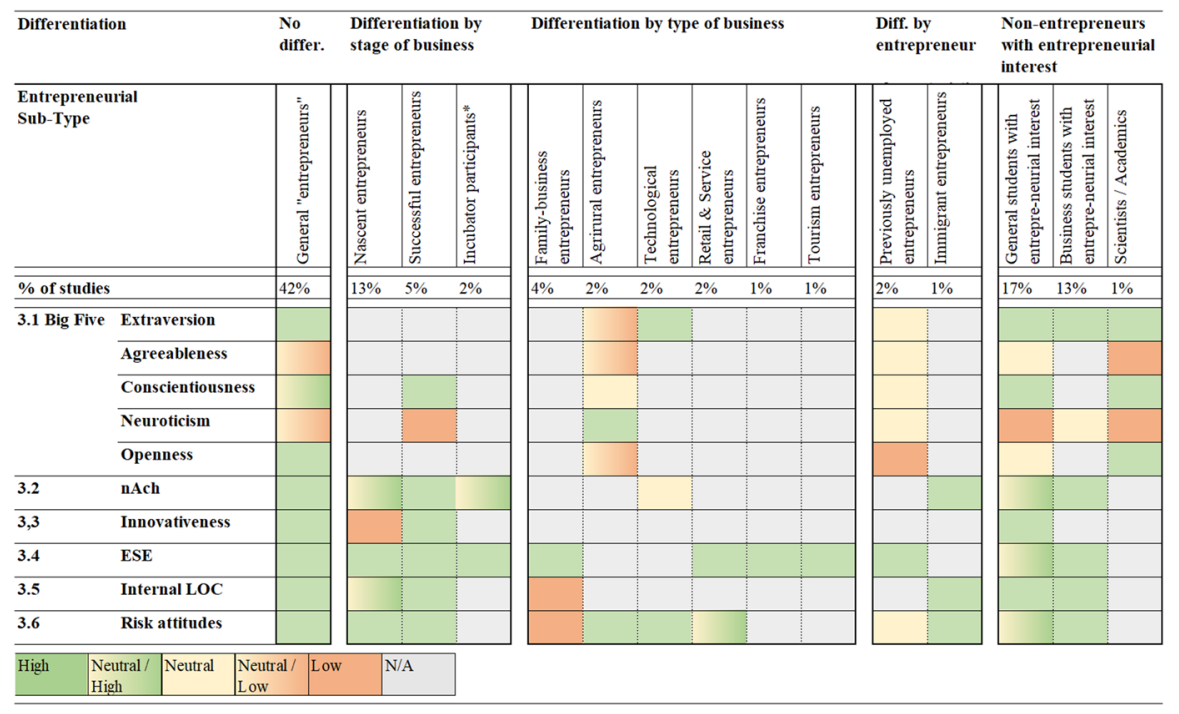

Fig. 2 Entrepreneur sub-types from literature review. *Incubator participants arguably can be counted to non-entrepreneurs if in pre-founding stage. Notes: Percentages add up to more than $100 \%$ because some studies examined more than one entrepreneurial sub-type; High risk-attitude means more risk-prone or less risk-averse; "General "entrepreneurs"” include general self-employed or general SME owners; Selected references for Fig. 2: Big Five (Roberts 1989; Schmitt-Rodermund 2004; Caliendo et al. 2014; Espíritu-Olmos and Sastre-Castillo 2015; Staniewski et al. 2016; Mei et al. 2017; Liang 2019; Yang and Ai 2019; López-Núñez et al. 2020), nAch (Ahmed 1985; Roberts 1989; Stewart et al. 1999; Lee and Tsang 2001; Hansemark 2003; Taormina and Lao 2007; Caliendo and Kritikos 2008; Altinay et al. 2012; Staniewski et al. 2016; Imran et al. 2019), Innovativeness (Stewart et al. 1999; Altinay et al. 2012; Lukes 2013; Hyytinen et al. 2015; Staniewski et al. 2016), ESE (Luthans and Ibrayeva 2006; Hmieleski and Corbett 2008; BarNir et al. 2011; Hopp and Stephan 2012; Cumberland et al. 2015; Staniewski et al. 2016; Schmitt et al. 2018; Boudreaux et al. 2019), Internal LOC (Lee and Tsang 2001; Hansemark 2003; Owens et al. 2013; Caliendo et al. 2014; Espíritu-Olmos and Sastre-Castillo 2015; Staniewski et al. 2016; Karimi et al. 2017; Kerr et al. 2019; Voda and Florea 2019), Risk attitudes (Cramer et al. 2002; Macko and Tyszka 2009; Masclet et al. 2009; Caliendo et al. 2010, 2014; Brown et al. 2011; Kreiser et al. 2013; Niess and Biemann 2014; Skriabikova et al. 2014; Kerr et al. 2019)

There are several potential explanations for these inconsistent findings. First, the inconsistencies may be due to the lack of an agreed-upon Risk attitude measure. While some studies used self-reported measures, others used behavioral or indirect measures of Risk attitudes. Second, the inconsistencies may be due to definitional variation. Few of the studies on Risk-taking differentiated between entrepreneur sub-types even though there are likely substantial differences between these subtypes in terms of Risk attitudes. For example, the level of Risk-taking propensity of opportunity-driven entrepreneurs exceeds that of necessity-driven entrepreneurs (Block et al. 2015), and students in the planning phase of a future entrepreneurial venture exceed already practicing entrepreneurs in terms of their level of Risk-taking propensity (Antoncic et al. 2018). Future research should employ methodological designs that allow for direct and simultaneous comparisons between a variety of entrepreneur sub-types in terms of Risk-taking propensity. 


\section{Integrated insights per entrepreneur sub-type}

In the next part, we pivot our approach from the perspective of personality traits to the perspective of entrepreneur sub-types. As part of our literature review, we classified each paper in terms of the entrepreneur sample used. The list of potential entrepreneur sub-types is infinite, and this is one of the potential problems in defining the traits of an entrepreneur. Nevertheless, in Fig. 2, we present all entrepreneur sub-types that emerged from the papers included in the sample in our literature review and classify them according to the six outlined personality traits. Then, we offer some insights into six selected entrepreneur sub-types.

\subsection{Characteristics of selected entrepreneur sub-types}

For the following analysis, we selected six exemplary entrepreneur sub-types in the academic literature to date. An explanation of these sub-types can help to elucidate how definitional variations relate to differences in the personality profiles.

The entrepreneurial archetype While little attention has been given to differentiating entrepreneur sub-types, many studies have investigated what personality defines entrepreneurs in general. Despite various sub-types likely differing, the combination of several sub-types has frequently been tested when investigating entrepreneurs. These studies including samples of general entrepreneurs have largely revealed a pattern of E+, C+, O+, N-, and A- for the Big Five (Schmitt-Rodermund 2004; Antoncic et al. 2015); high nAch (Stewart et al. 1999; Imran et al. 2019); high ESE (Imran et al. 2019; Kerr et al. 2019); high internal LOC (Kerr et al. 2019); and, typically, a U-shaped risk-propensity relationship (Antoncic et al. 2018). At the same time, various entrepreneur sub-types have frequently been extrapolated to entrepreneurs in general, and differentiations have rarely been performed. Because of this, it is important to further investigate differences in individual entrepreneur sub-types.

Nascent entrepreneurs A sub-type of entrepreneurs that has frequently been examined is nascent or early-stage entrepreneurs. Again, the precise definitions and tested samples have varied significantly between studies and even within the category of nascent entrepreneurs. Thus, some studies on nascent entrepreneurs described their subjects as having founded a business up to several years ago (Staniewski et al. 2016); others referred to nascent entrepreneurs as general, early-stage entrepreneurs (Yang et al. 2020); and others included individuals who had only partially decided to start a business or who were in the founding stages (Dalborg et al. 2015). One study we mention in the previous paragraph also included samples of entrepreneurs along the founding process (Antoncic et al. 2015). While each approach is valid, it is difficult to draw combined insights regarding a general group of nascent entrepreneurs and even less so regarding entrepreneurs in general.

Nevertheless, some insights into the personality profile of nascent entrepreneurs can be drawn. Nascent entrepreneurs appear to differ from the entrepreneurial archetype. For nascent entrepreneurs, high Innovativeness does not seem to have the same favorable effect on firm survival (Hyytinen et al. 2015). Further, regarding nAch, 
there appear to be differences between early-stage entrepreneurs, i.e., individuals who have founded a business, and pre-stage entrepreneurs, i.e., those individuals who are interested in starting a business (Taormina and Lao 2007). The stronger their nAch is, the more likely individuals are to progress from the pre-stage to the early-founding stage.

Family business entrepreneurs Despite the existence of comprehensive definitions of family businesses (e.g. Donnelley 1964), most of the research on family businesses has not applied a consistent definition of what constitutes a family firm (Diéguez-Soto et al. 2015). In accordance with the high prevalence of family firms in most economies (Kraus et al. 2012), there has been at least some research on this entrepreneur sub-type. Succession planning within the family is a central component of family businesses, with the main motives typically being continuity over generations and family harmony (Gilding et al. 2014). Accordingly, a family background of entrepreneurship relates to higher entrepreneurial intention (Palmer et al. 2019a, b) in future generations. In our review, we noted that this sub-type of entrepreneurs differed from the entrepreneurial archetype, particularly regarding Risk attitudes and LOC. For example, contrary to general entrepreneurs, later generations of family business entrepreneurs show lower internal LOC (Zellweger et al. 2011).

Technological/tech-industry entrepreneurs One of the first associations that may come to mind when thinking about entrepreneurs is that of high-growth technology start-ups. Nevertheless, this sub-type of entrepreneurs has not yet received widespread academic attention in terms of personality classification. Individual studies on technical entrepreneurs have indicated that differences between this sub-type and more general entrepreneurs exist. For example, Roberts (1989) showed that technical entrepreneurs are more moderate in their nAch than would be expected of general entrepreneurs. Nevertheless, this is a sub-type of entrepreneurs that requires significantly more research attention.

Agrirural entrepreneurs The group of agrirural or farming entrepreneurs is a group that has received some attention in terms of empirical investigations. Further, we observed that the results related to this subgroup of entrepreneurs were frequently extrapolated to entrepreneurs in general, often without a clear description of the agrirural sample in the title or abstract (Sohn 2017). This was the case despite agrirural entrepreneurs differing from general entrepreneurs in several ways. For example, while there is a relationship between Conscientiousness and entrepreneurial activity for general entrepreneurs (Antoncic et al. 2015), agrirural entrepreneurs' alertness is only partially affected through higher Conscientiousness (Liang 2019). Yang and Ai (2019) further demonstrated that agrirural entrepreneurs differ from self-employed non-agrirural, self-employed entrepreneurs in the Big Five dimensions. We encourage all future studies with agrirural entrepreneurs as their sample to clearly state that this sub-type is being tested.

Students with entrepreneurial interest As outlined previously, students have frequently been relied upon in empirical papers that attempt to characterize actual entrepreneurs. The number of studies that have done so is surprisingly high-in our initial, prefiltered sample of studies, approximately $30 \%$ used some form of student sample. However, it is highly questionable whether students can be part of the entrepreneur sub-type at all, as they mostly have not yet founded a venture. Despite 
students not having founded a business yet, students with entrepreneurial interest have frequently been used as samples when investigating the entrepreneurial personality. These studies are inherently limited to investigations on entrepreneurial intention rather than activity because the students in the samples will not yet have founded a business.

Nevertheless, due to their frequent use as entrepreneurial proxies, it is worth considering in what ways these students with entrepreneurial interest are similar to or different from actual entrepreneurs. In some ways, entrepreneurially oriented students share personality dimensions with practicing entrepreneurs. For example, entrepreneurially interested students have high levels of Extraversion and Risk-propensity (Espíritu-Olmos and Sastre-Castillo 2015), as well as high ESE (Chen et al. 1998). Simultaneously, entrepreneurially interested students differ from practicing entrepreneurs in several important personality dimensions. For example, Openness to Experience (Mei et al. 2017) and Neuroticism (Espíritu-Olmos and Sastre-Castillo 2015) appear to have marginal effect on entrepreneurial intention for students. Despite these indications our review can offer, we cannot draw direct conclusions on the validity of using student proxies for entrepreneur samples until direct comparisons are performed between both types of samples in future empirical studies.

\subsection{Integrated insights from entrepreneur sub-types}

Across the different personality traits and entrepreneur sub-types we deduced five major observations from our literature review. First, we noted that the general category of "entrepreneur" has received significant academic interest but without further differentiation of any entrepreneur sub-types despite substantial differences between these groups. Thus, we observed a vast number of disjointed studies specific to entrepreneur sub-types, industries, or business types.

Second, those few entrepreneur sub-types that have been researched show different personality profiles. Thus, there appears to not be a general "entrepreneur" profile that fits all sub-types. Instead, there are significant differences between the individual types. This should encourage future research to perform further differentiations between entrepreneur sub-types.

Third, the extent to which individual personality traits have received attention in academic literature varies. While Risk attitudes and the Big Five have received significant academic attention, other traits that may be even more central to the entrepreneur personality profile require further empirical support. For example, Innovativeness may be a core factor differentiating entrepreneurs from non-entrepreneurs. Despite this, the empirical investigations are limited and to our knowledge, no literature review focusing solely on entrepreneurial Innovativeness as a personality trait exists.

Fourth, the personality traits differ in terms of their results. While there are some personality traits that show consistent findings independent of entrepreneur sub-type, others show more diverse results depending on the entrepreneur sub-type examined. For example, ESE was generally high for general entrepreneurs and for 
all entrepreneur sub-types analyzed in our review. In contrast, Risk attitudes showed more diverse results.

Our last main observation is that approximately $30 \%$ of the studies in our literature review sample tested students despite claiming to investigate entrepreneur personalities. Students with or without entrepreneurial interest are frequently used as proxies in the entrepreneurship literature, perhaps because of their easy accessibility. However, drawing inferences from their traits toward entrepreneur characteristics in general may be difficult, as they are not actual entrepreneurs.

\section{Discussion}

\subsection{Summary and contributions}

This literature review used a systematic literature review methodology (Tranfield et al. 2003) to analyze differences in personality traits across various entrepreneur sub-types. Our literature review examined entrepreneur sub-types and the extent of the differentiation performed in previous papers across six personality traits. ${ }^{4} \mathrm{We}$ were led by three main research objectives, which we investigated throughout our review.

First, we explored whether the previous research on entrepreneurial personality varied in its definitions in the way we had assumed. Here, we noted that previous research had extreme variation in the definition of the term "entrepreneur". In fact, some studies did not provide an explicit definition in their sample description. The literature reviews and meta-analyses in our review also rarely made explicit distinctions between entrepreneur sub-types, meaning they compared studies that used vastly different samples.

Second, we examined whether there were inconsistent findings in the previous research. Without being able to infer causality from a literature review, one potential explanation for such inconsistencies is the use of different definitions. Indeed, we observed that the findings differed strongly between various studies. In most of these cases of inconsistencies, different entrepreneurial samples had been used. We explicitly noted that causality cannot be inferred from such observations alone. Third, we outlined the personality differences between entrepreneur sub-types in the few studies that differentiated between them. When studies differentiated between entrepreneur sub-types, there were typically observable personality differences between the sub-types.

Based on these observations, we make two main contributions to research on entrepreneurial personality traits. First, through our literature review, we demonstrate the importance of being specific in samples and definitions. Previous research has used widely different definitions of entrepreneurs, consequently testing discrepant samples, and revealing somewhat inconsistent results. While we cannot infer

\footnotetext{
4 The personality traits are (1) the Big Five, (2) Need for Achievement (nAch), (3) Innovativeness, (4) Entrepreneurial Self-efficacy (ESE), (5) Locus of Control (LOC), and (6) Risk attitudes.
} 
causality from this alone, the possibility exists that these inconsistencies are due to definitional variations, which we highly encourage future research to investigate. We acknowledge that several other explanations could account for these inconsistencies, such as a lack of agreed-upon personality trait measures. We encourage future research to employ methodological designs that allow for direct and simultaneous comparisons between a variety of entrepreneur sub-types across personality traits. This would enable us to differentiate between entrepreneur types in terms of personality more clearly. In addition, our literature review shows that research must aim to precisely define the samples tested. Future literature reviews and meta-analyses should further differentiate between the different samples used in the studies they analyze, as combining the results of studies with vastly different entrepreneurial samples may lead to inaccurate findings.

Second, our literature review shows that it may be misleading to test samples consisting of non-entrepreneurs with entrepreneurial interest when aiming to investigate entrepreneurial personalities in general. At best, testing non-entrepreneurs, such as students with entrepreneurial interest, can shed light on the personalities behind entrepreneurial intentions, but such testing cannot give insights per se about individuals who have already founded a business. Thus, we further highlight the importance of being specific in defining samples and encourage the clear labeling of non-entrepreneur samples in future research.

The question arises of what follows from these initial observations. While we explicitly do not encourage every review or study to apply the same definition of entrepreneur, we strongly emphasize the need to make the definition used explicit and for future reviews to continue to systematically analyze the different samples used in individual studies. If possible, future research should rely more strongly on practicing entrepreneurs as samples when investigating the nature of the entrepreneurial personality.

\subsection{Limitations of this study}

This literature review assessed previous reviews and empirical studies on entrepreneurial personalities to investigate whether discrepancies in their findings could be explained by variations in the definition of the term "entrepreneur." While this study sheds light on a more differentiated view of entrepreneurial personality, it does not enable us to make causal inferences. Further, inferences cannot be made as to whether specific traits predict entrepreneurial behavior or whether specific traits emerge because of entrepreneurial activity.

Beyond this, we recognize that the nature of the studies included in our sample may constitute a limitation. The studies on entrepreneurial personality to date have generally involved small sample sizes and have been heavily reliant on questionnaires. These questionnaires are self-report measures, where participants are free to give their own judgments but are also free to-consciously or unconsciouslydeviate from their actual views and behaviors. Participants may be inclined to present a more positive view of themselves in a questionnaire, although such social 
desirability biases are not observed as frequently as one might expect (Conway and Lance 2010). To validate outcomes from self-report measures, behavioral tests can be used by measuring observable behavior, which is not as biased by participant adjustments. This is particularly relevant in the field of personality research, where individuals may want to portray themselves as favorably as possible. To counteract this, fake-proof measures have been developed for various personality traits, such as the Big Five (Hirsh and Peterson 2008). Other indirect methods, such as behavioral tests using reaction times or semi-structured interviews or the use of statistical rectifications (Podsakoff et al. 2003), may provide more reliable information on individuals' personalities.

Relatedly, while this literature review focused on the lack of differentiation between entrepreneur sub-types in previous research, it must be made clear that the observed discrepancies may also stem from alternative reasons. For example, the discrepancies could be due to the inconsistent use of personality-assessment measures. For example, there are more than 20 different instruments that can be used to take nAch measurements of entrepreneurs (Stewart and Roth 2007), including both projective and objective measurements. Another reason could be that cultural differences among the multitude of countries in the sampled studies play a larger role than we considered in this review.

Finally, throughout this literature review, we investigated whether there were any differences between entrepreneur sub-types. While we were often able to report such differences and their statistical direction, we were largely unable to draw conclusions about the scale of these differences. For this, further empirical investigations are necessary.

\subsection{Future research}

First, in line with the main thesis of this review, we encourage future studies to define the term "entrepreneur" and describe, in detail, their entrepreneur samples more explicitly. As such, we view this as a factor of methodological correctness. This would not only make the results of individual studies more comparable but also allow for systematic differentiation between various entrepreneur sub-types. Since these sub-types are often unalike, such differentiation would likely allow for observations of discrete personality traits depending on entrepreneur type. This would advance our academic understanding of what traits define entrepreneurs and would have a variety of practical implications, such as for tailored entrepreneurial education programs.

Second, personalities are not limited to the six traits discussed in this review. There are a multitude of potential personality traits that could be investigated in research on entrepreneurs. Limiting research to a specific subset of personality traits may lead to important findings being missed. For example, this review may have focused too strongly on the positive aspects of entrepreneurial personalities. Increasingly, research is beginning to emphasize the potential "downsides" of 
entrepreneurial personalities (Miller 2015, 2016; Klotz and Neubaum 2016). Systematic investigations into the differences between entrepreneur sub-types in personality traits beyond those explored in this review would further develop our understanding of entrepreneurial personalities.

Third, it is likely insufficient to study personality traits as stand-alone constructs. Instead, personality traits must always be viewed within personal and environmental contexts, which requires the involvement of other factors, such as an individual's attitude, self-identity, culture, and social environment. Further, when regarding later stages of entrepreneurial ventures and their performance, factors attributed to the ventures on a firm-level interact with individual personality traits (Palmer et al. 2019a, b). While experimental designs are naturally limited to a set of variables, future research should consider some of these additional factors when investigating entrepreneur personality traits.

Fourth, we encourage future research to branch out to novel research methodologies and designs. As already discussed, previous studies in this field have largely relied on self-report questionnaires, which may not be the most reliable means of gathering information, as self-reported findings are inherently biased (Donaldson and Grant-Vallone 2002). Novel techniques from other disciplines would be valuable additions to research on entrepreneurs. For example, expanding the use of neurological imaging techniques, such as fMRI scans (LedezmaHaight et al. 2016), or examining the genetic basis of entrepreneurial personality traits using twin studies (Nicolaou et al. 2008; Shane et al. 2010; Shane and Nicolaou 2013) could offer novel insights into the field of entrepreneur personality.

\section{Appendix 1: Search methodology}

Search string used:

Web of Science: "title: ((trait* OR personality OR character* OR Big Five OR Need for achievement OR Self-Efficacy OR Innovative* OR Locus of Control OR Risk) AND (self-employ* OR SME OR Start-up OR Startup OR Entrepr* OR Micro business OR Micro-business OR Small business OR Medium business))”.

\section{Appendix 2: Previous literature reviews and meta-analyses}

See Table 2 . 


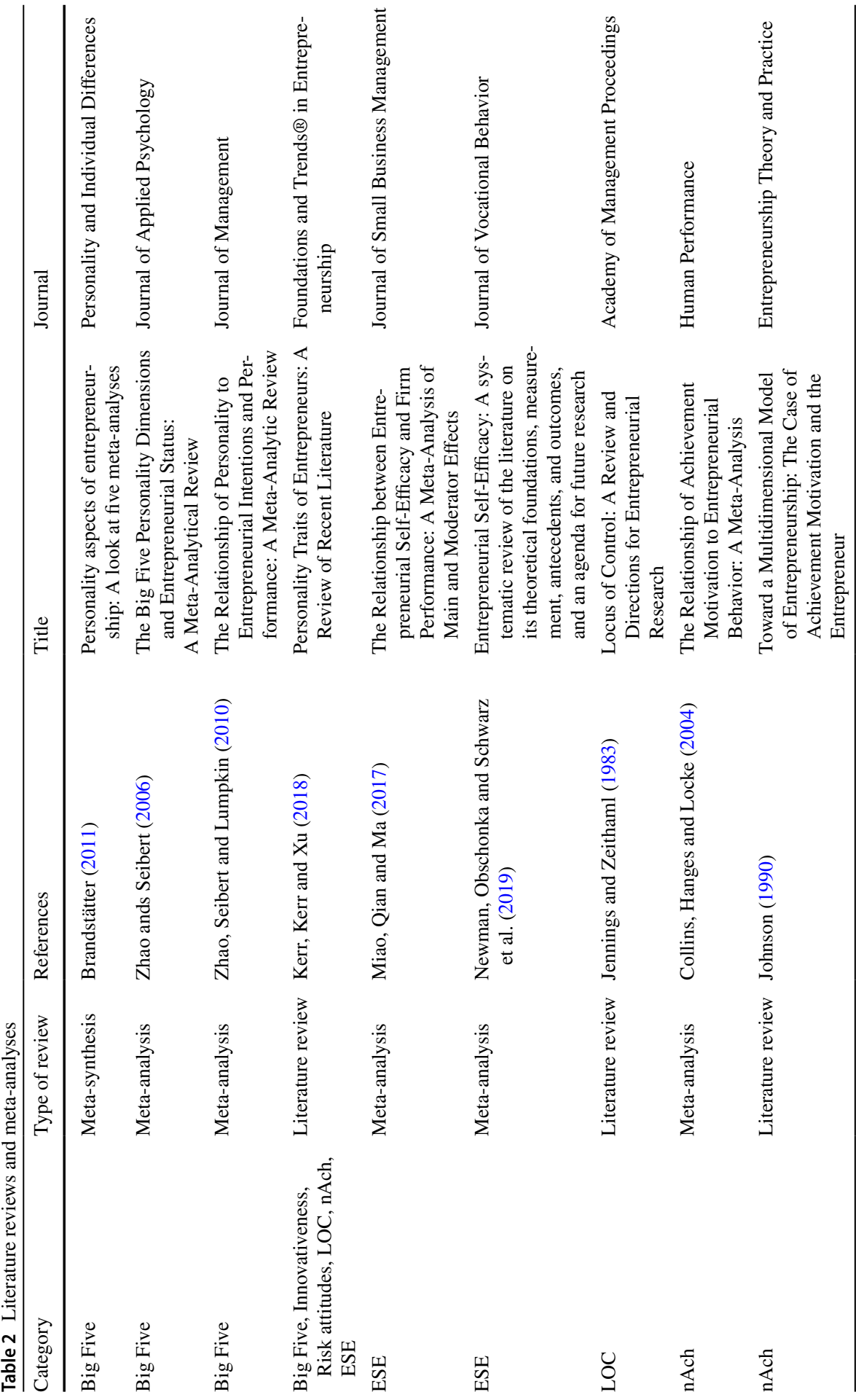




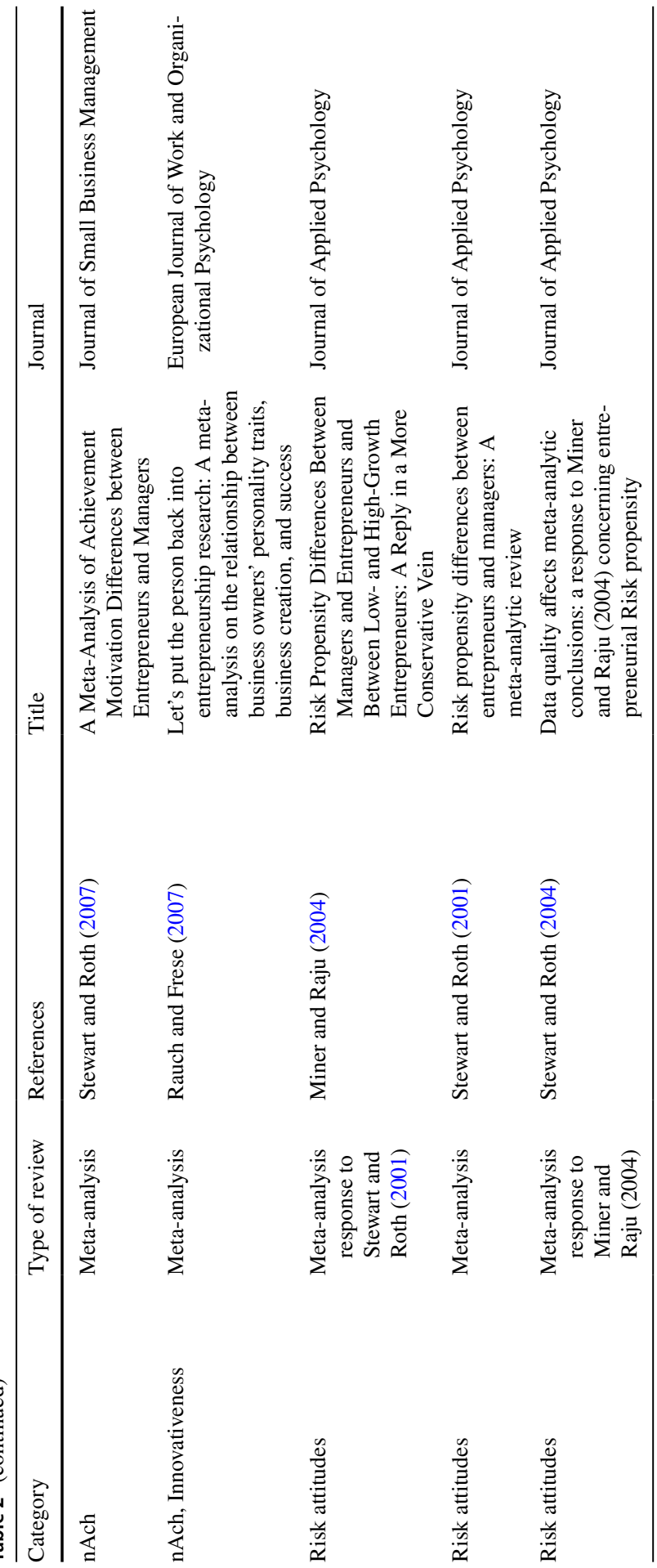


Funding Open Access funding enabled and organized by Projekt DEAL. Not applicable/No external funding.

Data availability Tables of individual studies analyzed in the literature review provided to the Open Science Framework.

\section{Declarations}

Conflict of interest The authors declare that they have no conflict of interest.

Open Access This article is licensed under a Creative Commons Attribution 4.0 International License, which permits use, sharing, adaptation, distribution and reproduction in any medium or format, as long as you give appropriate credit to the original author(s) and the source, provide a link to the Creative Commons licence, and indicate if changes were made. The images or other third party material in this article are included in the article's Creative Commons licence, unless indicated otherwise in a credit line to the material. If material is not included in the article's Creative Commons licence and your intended use is not permitted by statutory regulation or exceeds the permitted use, you will need to obtain permission directly from the copyright holder. To view a copy of this licence, visit http://creativecommons.org/licen ses/by/4.0/.

\section{References}

Ahmed SU (1985) nAch, risk-taking propensity, locus of control and entrepreneurship. Personal Individ Differ 6(6):781-782

Ajzen I (1991) The theory of planned behavior. Organ Behav Hum Decis Process 50:179-211

Altinay L, Madanoglu M, Daniele R, Lashley C (2012) The influence of family tradition and psychological traits on entrepreneurial intention. Int J Hosp Manag 32:489-499

Anderson CR (1977) Locus of control, coping behaviors, and performance in a stress setting: a longitudinal study. J Appl Psychol 62(4):446-451

Andrisani PJ, Nestel G (1976) Internal-external control as contributor to and outcome of work experience. J Appl Psychol 61(2):156-165

Antoncic B, Bratkovic Kregar T, Singh G, DeNoble AF (2015) The big five personality-entrepreneurship relationship: evidence from Slovenia. J Small Bus Manag 53(3):819-841

Antoncic J, Antoncic B, Gantar M, Hisrich RD, Marks LJ, Bachkirov AA, Li Z, Polzin P, Borges JL, Coelho A, Kakkonen M-L (2018) Risk-taking propensity and entrepreneurship: the role of power distance. J Enterp Cult 26(01):1-26

Astebro T, Herz H, Nanda R, Weber RA (2014) Seeking the roots of entrepreneurship: insights from behavioral economics. J Econ Perspect 28(3):49-70

Bachmann AK, Maran T, Furtner M, Brem A, Welte M (2020) Improving entrepreneurial self-efficacy and the attitude towards starting a business venture. Rev Manag Sci p 1-21

Bandura A (2010) Self-Efficacy. Wiley, Hoboken

BarNir A, Watson WE, Hutchins HM (2011) Mediation and moderated mediation in the relationship among role models, self-efficacy, entrepreneurial career intention, and gender. J Appl Soc Psychol 41(2):270-297

Begley TM, Boyd DP (1987) A comparison of entrepreneurs and managers of small business firms. J Manag 13(1):99-108

Bellu RR, Davidsson P, Goldfarb C (1990) Toward a theory of entrepreneurial behaviour; empirical evidence from Israel, Italy and Sweden. Entrep Reg Dev 2(2):195-209

Biraglia A, Kadile V (2017) The role of entrepreneurial passion and creativity in developing entrepreneurial intentions: insights from American homebrewers. J Small Bus Manag 55(1):170-188

Block J, Sandner P, Spiegel F (2015) how do risk attitudes differ within the group of entrepreneurs? The role of motivation and procedural utility. J Small Bus Manag 53(1):183-206

Bosma N, Content J, Sanders M, Stam E (2018) Institutions, entrepreneurship, and economic growth in Europe. Small Bus Econ 51(2):483-499 
Boudreaux CJ, Nikolaev BN, Klein P (2019) Socio-cognitive traits and entrepreneurship: the moderating role of economic institutions. J Bus Ventur 34(1):178-196

Brandstätter H (2011) Personality aspects of entrepreneurship: a look at five meta-analyses. Personal Individ Differ 51(3):222-230

Brem A (2011) Linking innovation and entrepreneurship-literature overview and introduction of a process-oriented framework. Int J Entrep Innov Manag 14:6-35

Brown S, Dietrich M, Ortiz-Nuñez A, Taylor K (2011) Self-employment and attitudes towards risk: timing and unobserved heterogeneity. J Econ Psychol 32(3):425-433

Caliendo M, Kritikos A (2008) Is Entrepreneurial success predictable? An ex-ante analysis of the character-based approach. Kyklos 61:189-214

Caliendo M, Fossen F, Kritikos A (2010) The impact of risk attitudes on entrepreneurial survival. J Econ Behav Organ 76(1):45-63

Caliendo M, Fossen F, Kritikos A (2014) Personality characteristics and the decisions to become and stay self-employed. Small Bus Econ 42(4):787-814

Cassidy T, Lynn R (1989) A multifactorial approach to achievement motivation: the development of a comprehensive measure. J Occup Psychol 62(4):301-312

Chan K-Y, Uy MA, Chernyshenko OS, Ho M-HR, Sam Y-L (2015) Personality and entrepreneurial, professional and leadership motivations. Personality Individ Differ 77:161-166

Chell E, Haworth JM, Brearley S (1991) The Entrepreneurial personality: concepts, cases, and categories. Routledge, Abingdon, UK

Chen C, Greene PG, Crick A (1998) Does entrepreneurial self-efficacy distinguish entrepreneurs from managers? J Bus Ventur 13(4):295-316

Chen G, Gully SM, Eden D (2001) Validation of a new general self-efficacy scale. Organ Res Methods 4(1):62-83

Collins C, Hanges P, Locke E (2004) The relationship of achievement motivation to entrepreneurial behavior: a meta-analysis. Hum Perform 17:95-117

Conway J, Lance C (2010) What reviewers should expect from authors regarding common method bias in organizational research. J Bus Psychol 25:325-334

Costa PT, McCrae RR (1992a) The five-factor model of personality and its relevance to personality disorders. J Personal Disord 6(4):343-359

Costa PT, McCrae RR (1992b) Normal personality assessment in clinical practice: the NEO personality inventory. Psychol Assess 4(1):5-13

Cramer J, Hartog J, Jonker N, Praag M (2002) Low risk aversion encourages the choice for entrepreneurship: an empirical test of a truism. J Econ Behav Organ 48(1):29-36

Cromie S, Johns S (1983) Irish entrepreneurs: some personal characteristics. J Occup Behav 4(4):317-324

Cucculelli M, Ermini B (2013) Risk attitude, product innovation, and firm growth. evidence from Italian manufacturing firms. Econ Lett 118:275-279

Culbertson SS, Smith MR, Leiva PI (2011) Enhancing entrepreneurship: the role of goal orientation and self-efficacy. J Career Assess 19(2):115-129

Cumberland D, Meek W, Ph.D R, (2015) Entrepreneurial self-efficacy and firm performance in challenging environments: evidence from the franchise context. J Dev Entrep 20:1550004

Dalborg C, von Friedrichs Y, Wincent J (2015) Risk perception matters: why women's passion may not lead to a business start-up. Int J Gend Entrep 7(1):87-104

Dalton PS, Nhung N, Rüschenpöhler J (2020) Worries of the poor: the impact of financial burden on the risk attitudes of micro-entrepreneurs. J Econ Psychol 79:102198

Diéguez-Soto J, López-Delgado P, Rojo-Ramírez A (2015) Identifying and classifying family businesses. Rev Manag Sci 9(3):603-634

Donaldson SI, Grant-Vallone EJ (2002) Understanding self-report bias in organizational behavior research. J Bus Psychol 17(2):245-260

Donnelley R (1964) The family business. Harv Bus Rev 42:93-105

Douglas EJ (2013) Reconstructing entrepreneurial intentions to identify predisposition for growth. J Bus Ventur 28(5):633-651

Drnovsek M, Wincent J, Cardon M (2010) Entrepreneurial self-efficacy and business start-up: developing a multidimensional definition. Int J Entrep Behav Res 16:329-348

Eeckhoudt L, Schlesinger H (2013) Higher-order risk attitudes. In: Dionne G (ed) Handbook of insurance. Springer, New York, pp 41-57

Espíritu-Olmos R, Sastre-Castillo MA (2015) Personality traits versus work values: comparing psychological theories on entrepreneurial intention. J Bus Res 68(7):1595-1598 
Ferreira JJM, Fernandes CI, Kraus S (2019) Entrepreneurship research: mapping intellectual structures and research trends. Rev Manag Sci 13(1):181-205

Fiske DW (1949) Consistency of the factorial structures of personality ratings from different sources. Psychol Sci Public Interest 44(3):329-344

Gilding M, Gregory S, Cosson B (2014) Motives and outcomes in family business succession planning. Entrep Theory Pract 39(2):299-312

Goldberg LR (1990) An alternative "description of personality": the Big-Five factor structure. J Pers Soc Psychol 59(6):1216-1229

Goldsmith R, Foxall G (2003) The Measurement of innovativeness. In: Shavinina L (ed) The international handbook on innovation. Elsevier Science, Oxford UK, pp 321-330

Hallak R, Assaker G, O'Connor P (2014) Are family and nonfamily tourism businesses different? An examination of the entrepreneurial self-efficacy-entrepreneurial performance relationship. J Hosp Tour Res 38:388-413

Hansemark O (2003) Need for achievement, locus of control and the prediction of business start-ups: a longitudinal study. J Econ Psychol 24:301-319

Hart JW, Stasson MF, Mahoney JM, Story P (2007) The Big Five and achievement motivation: exploring the relationship between personality and a two-factor model of motivation. Individ Differ Res 5(4):267-274

Hechavarria D, Renko M, Matthews C (2012) The nascent entrepreneurship hub: goals, entrepreneurial self-efficacy and start-up outcomes. Small Bus Econ 39:1-17

Hemmasi M, Hoelscher M (2005) Entrepreneurship research: using students as proxies for actual entrepreneurs. J Entrep Educ 8:49-59

Hirsh JB, Peterson JB (2008) Predicting creativity and academic success with a "fake-proof" measure of the Big Five. J Res Personal 42(5):1323-1333

Hmieleski K, Corbett A (2008) The contrasting interaction effects of improvisational behavior with entrepreneurial self-efficacy on new venture performance and entrepreneur work satisfaction. J Bus Ventur 23:482-496

Hopp C, Stephan U (2012) The influence of socio-cultural environments on the performance of nascent entrepreneurs: community culture, motivation, self-efficacy and start-up success. Entrep Reg Dev 24:917-945

Hornaday JA, Aboud J (1971) Characteristics of successful entrepreneurs. Personal Psychol 24(2):141-153

Hurt HT, Joseph K, Cook CD (1977) Scales for the measurement of innovativeness. Hum Commun Res 4(1):58-65

Hvide H, Panos G (2014) Risk tolerance and entrepreneurship. J Financ Econ 111(1):200-223

Hyun S-H, Seo M-K, Choi SK (2019) Does self-efficacy always trigger entrepreneurial intention?: An exploratory approach. Manag Stud

Hyytinen A, Pajarinen M, Rouvinen P (2015) Does innovativeness reduce startup survival rates? J Bus Ventur 30(4):564-581

Imran T, Ahmed R, Streimikiene D, Soomro DR, Parmar V, Vveinhardt J (2019) Assessment of entrepreneurial traits and small-firm performance with entrepreneurial orientation as a mediating factor. Sustainability 11:1-23

Ispir O, Elibol E, Sonmez B (2019) The relationship of personality traits and entrepreneurship tendencies with career adaptability of nursing students. Nurse Educ Today 79:41-47

Jackson D (1994) Jackson personality inventory. Research Psychologists Press, Goshen, NY

Jennings D, Zeithaml C (1983) Locus of control: a review and directions for entrepreneurial research. Acad Manag Proc 1983:417-421

John OP, Srivastava S (1999) The Big Five trait taxonomy: history, measurement, and theoretical perspectives. In: Pervin L, John OP (eds) Handbook of personality: theory and research, 2nd edn. Guilford Press, New York, pp 102-138

Johnson BR (1990) Toward a multidimensional model of entrepreneurship: the case of achievement motivation and the entrepreneur. Entrep Theory Pract 14(3):39-54

Josef AK, Richter D, Samanez-Larkin GR, Wagner GG, Hertwig R, Mata R (2016) Stability and change in risk-taking propensity across the adult life span. J Personal Soc Psychol 111(3):430-450

Karimi S, Biemans H, Mahdei K, Lans T, Chizari M, Mulder M (2017) Testing the relationship between personality characteristics, contextual factors and entrepreneurial intentions in a developing country. Int J Psychol 52:227-240 
Kerr S, Kerr W, Xu T (2018) Personality traits of entrepreneurs: a review of recent literature. Found Trends® Entrep 14:279-356

Kerr S, Kerr W, Dalton M (2019) Risk attitudes and personality traits of entrepreneurs and venture team members. Proc Natl Acad Sci 116(36):17712-17716

Kirton M (1976) Adaptors and innovators: a description and measure. J Appl Psychol 61(5):622-629

Klotz AC, Neubaum DO (2016) Article commentary: research on the dark side of personality traits in entrepreneurship: observations from an organizational behavior perspective. Entrep Theory Pract 40(1):7-17

Knight FH (1921) Risk uncertainty and profit houghton. Mifflin, Boston, MA

Kolvereid L, Isaksen E (2006) New business start-up and subsequent entry into self-employment. J Bus Ventur 21(6):866-885

Kormanik M, Rocco T (2009) Internal versus external control of reinforcement: a review of the locus of control construct. Hum Resour Dev Rev 8:463-483

Kraus S, Pohjola M, Koponen A (2012) Innovation in family firms: an empirical analysis linking organizational and managerial innovation to corporate success. Rev Manag Sci 6(3):265-286

Kraus S, Breier M, Jones P, Hughes M (2019) Individual entrepreneurial orientation and intrapreneurship in the public sector. Int Entrep Manag J 15:1247-1268

Kraus S, Breier M, Dasí-Rodríguez S (2020) The art of crafting a systematic literature review in entrepreneurship research. Int Entrep Manag J 16(3):1023-1042

Kreiser P, Marino L, Kuratko D, Weaver K (2013) Disaggregating entrepreneurial orientation: the nonlinear impact of innovativeness, proactiveness and risk-taking on SME performance. Small Bus Econ 40:273-291

Krueger N, Dickson PR (1994) How believing in ourselves increases risk taking: perceived self-efficacy and opportunity recognition. Decis Sci 25(3):385-400

Lachman ME (1986) Locus of control in aging research: a case for multidimensional and domain-specific assessment. Psychol Aging 1(1):34-40

Laguna M (2013) Self-efficacy, self-esteem, and entrepreneurship among the unemployed. J Appl Soc Psychol 43(2):253-262

Ledezma-Haight R, Ramos Bruach M, Prčkovska V, Rodrigues P, Gallardo-Pujol D (2016) Wired minds: how personality traits can predict entrepreneurs' brains. Personal Individ Differ 101:493

Lee C, Bobko P (1994) Self-efficacy beliefs: comparison of five measures. J Appl Psychol 79(3):364-369

Lee D, Tsang E (2001) The effects of entrepreneurial personality, background and network activities on venture growth. J Manag Stud 38(4):583-602

Lefcourt HM (1972) Recent developments in the study of locus of control. Academic Press, Oxford, England

Levenson H (1973) Multidimensional locus of control in psychiatric patients. J Consult Clin Psychol 41(3):397-404

Liang C (2019) How entrepreneur personality affects agrirural entrepreneurial alertness. J Entrep Manag Innov 15:147-170

Llewellyn DJ, Sanchez X, Asghar A, Jones G (2008) Self-efficacy, risk taking and performance in rock climbing. Personal Individ Differ 45(1):75-81

López-Núñez MI, Rubio-Valdehita S, Aparicio-García ME, Díaz-Ramiro EM (2020) Are entrepreneurs born or made? The influence of personality. Personal Individ Differ 154:109699

Lukes M (2013) Entrepreneurs as innovators: a multi-country study on entrepreneurs' innovative behaviour. Prague Econ Pap 22:72-84

Lukes M, Stephan U (2017) Measuring employee innovation: a review of existing scales and the development of the innovative behavior and innovation support inventories across cultures. Int $\mathrm{J}$ Entrep Behav Res 23:136-158

Lukes M, Stephan U, Černíková A (2009) Measuring innovative behavior and innovation support. In: 2nd ISPIM innovation symposium. New York

Luthans F, Ibrayeva ES (2006) Entrepreneurial self-efficacy in Central Asian transition economies: quantitative and qualitative analyses. J Int Bus Stud 37(1):92-110

Macko A, Tyszka T (2009) Entrepreneurship and risk taking. Appl Psychol 58(3):469-487

Marsh HW, Richards GE (1986) The Rotter locus of control scale: the comparison of alternative response formats and implications for reliability, validity, and dimensionality. J Res Personal 20(4):509-528

Masclet D, Colombier N, Denant-Boemont L, Lohéac Y (2009) Group and individual risk preferences: a lottery-choice experiment with self-employed and salaried workers. J Econ Behav Organ 70(3):470-484 
Mata R, Josef AK, Hertwig R (2016) Propensity for risk taking across the life span and around the globe. Psychol Sci 27(2):231-243

Maurer TJ, Pierce HR (1998) A comparison of Likert scale and traditional measures of self-efficacy. J Appl Psychol 83(2):324-329

Mazzarol T, Reboud S (2020) Entrepreneurship and innovation. Springer Nature, Singapore

McCarthy D, Puffer S, Lamin A (2018) Entrepreneurial orientation in a hostile and turbulent environment: risk and innovativeness among successful Russian entrepreneurs. Eur J Int Manag 12:191-221

McClelland DC (1961) The achieving society. Van Nostrand, Oxford, UK

McClelland DC, Atkinson JW, Clark RA, Lowell EL (1953) The achievement motive. Appleton-CenturyCrofts, East Norwalk, CT, US

McCrae RR, John OP (1992) An introduction to the five-factor model and its applications. J Personal 60(2):175-215

McGee J, Peterson M, Mueller S, Sequeira J (2009) Entrepreneurial self-efficacy: refining the measure. Entrep Theory Pract 33:965-988

Mei H, Ma Z, Jiao S, Chen X, Lv X, Zhan Z (2017) The Sustainable personality in entrepreneurship: the relationship between big six personality, entrepreneurial self-efficacy, and entrepreneurial intention in the Chinese context. Sustainability 9(9):1-23

Meyer HH, Walker WB, Litwin GH (1961) Motive patterns and risk preferences associated with entrepreneurship. Psychol Sci Public Interest 63(3):570-574

Miao C, Qian S, Ma D (2017) The relationship between entrepreneurial self-efficacy and firm performance: a meta-analysis of main and moderator effects. J Small Bus Manag 55(1):87-107

Midgley DF, Dowling GR (1978) Innovativeness: the concept and its measurement. J Consum Res 4(4):229-242

Miller D (2015) A downside to the entrepreneurial personality? Entrep Theory Pract 39(1):1-8

Miller D (2016) Article commentary: response to "research on the dark side of personality traits in entrepreneurship: observations from an organizational behavior perspective." Entrep Theory Pract 40(1):19-24

Miner JB, Raju NS (2004) Risk propensity differences between managers and entrepreneurs and between low- and high-growth entrepreneurs: a reply in a more conservative vein. J Appl Psychol 89(1):3-13

Mone MA (1994) Comparative validity of two measures of self-efficacy in predicting academic goals and performance. Educ Psychol Meas 54(2):516-529

Mubarak A, Irham MJ, Hartono S (2019) The influence of entrepreneurship characteristics and competencies on farmers' entrepreneurial intentions in the border region of North Borneo. IOP Conf Ser Earth Environ Sci 250(1):12-109

Mueller SL, Thomas AS (2001) Culture and entrepreneurial potential: a nine country study of locus of control and innovativeness. J Bus Ventur 16(1):51-75

Murray H (1938) Explorations in personality. Oxford University Press, New York

Newman A, Obschonka M, Schwarz S, Cohen M, Nielsen I (2019) Entrepreneurial self-efficacy: a systematic review of the literature on its theoretical foundations, measurement, antecedents, and outcomes, and an agenda for future research. J Vocat Behav 110:403-419

Nicolaou N, Shane S, Cherkas L, Atkins J, Spector T (2008) Is the tendency to engage in entrepreneurship genetic? Manag Sci 54:167-179

Niess C, Biemann T (2014) The role of risk propensity in predicting self-employment. J Appl Psychol 99(5):1000-1009

Obschonka M, Silbereisen RK, Schmitt-Rodermund E (2012) Explaining entrepreneurial behavior: dispositional personality traits, growth of personal entrepreneurial resources, and business idea generation. Career Dev Q 60(2):178-190

Ostendorf F, Angleitner A (1994) The five-factor taxonomy: robust dimensions of personality description. Psychologica Belgica 34(4):175-194

Owens K, Kirwan J, Lounsbury J, Levy J, Gibson L (2013) Personality correlates of self-employed small business owners' success. Work (Reading, Mass) 45:73-85

Palich LE, Bagby DR (1995) Using cognitive theory to explain entrepreneurial risk-taking: challenging conventional wisdom. J Bus Ventur 10(6):425-438

Palmer C, Fasbender U, Kraus S, Birkner S, Kailer N (2019a) A chip off the old block? The role of dominance and parental entrepreneurship for entrepreneurial intention. Rev Manag Sci 15:287-307 
Palmer C, Niemand T, Stöckmann C, Kraus S, Kailer N (2019b) The interplay of entrepreneurial orientation and psychological traits in explaining firm performance. J Bus Res 94:183-194

Pandey J, Tewary N (2011) Locus of control and achievement values of entrepreneurs. J Occup Psychol 52:107-111

Podsakoff P, MacKenzie S, Lee JY, Podsakoff N (2003) Common method biases in behavioral research: a critical review of the literature and recommended remedies. J Appl Psychol 88:879-903

Prodan I, Drnovsek M (2010) Conceptualizing academic-entrepreneurial intentions: an empirical test. Technovation 30:332-347

Rauch A, Frese M (2007) Let's put the person back into entrepreneurship research: a meta-analysis on the relationship between business owners' personality traits, business creation, and success. Eur J Work Organ Psychol 16(4):353-385

Reid DW (1985) Review of locus of control: current trends in theory and research. Can Psychol 26(1):69-70

Rhodes RE, Dickau L (2012) Experimental evidence for the intention-behavior relationship in the physical activity domain: a meta-analysis. Health Psychol 31(6):724-727

Roberts EB (1989) The personality and motivations of technological entrepreneurs. J Eng Technol Manag 6(1):5-23

Rotter JB (1966) Generalized expectancies for internal versus external control of reinforcement. Psychol Monogr Gen Appl 80(1):1-28

Scanlan TJ (1979) Self Employment as a career option: An investigation of entrepreneurship from theperspectives of Holland's theory of career development and levendon's measure of locus of control. Unpublished doctoral dissertation. University of Illinois at Urbana-Champaign

Schildberg-Hörisch H (2018) Are risk preferences stable? J Econ Perspect 32(2):135-154

Schjoedt L, Craig J (2017) Development and validation of a unidimensional domain-specific entrepreneurial self-efficacy scale. Int J Entrep Behav Res 23:98-113

Schmitt A, Rosing K, Zhang S, Leatherbee M (2018) A dynamic model of entrepreneurial uncertainty and business opportunity identification: exploration as a mediator and entrepreneurial self-efficacy as a moderator. Entrep Theory Pract 42:835-859

Schmitt-Rodermund E (2004) Pathways to successful entrepreneurship: parenting, personality, early entrepreneurial competence, and interests. J Vocat Behav 65(3):498-518

Schmitz A, Urbano D, Dandolini G, Souza J, Guerrero M (2017) Innovation and entrepreneurship in the academic setting: a systematic literature review. Int Entrep Manag J 13:369-395

Schumpeter J (1934) The theory of economic development. Harvard University Press, Cambridge, MA

Shane S (2003) A general theory of entrepreneurship: the individual-opportunity nexus. Edward Elgar, Northampton, MA

Shane S, Nicolaou N (2013) The genetics of entrepreneurial performance. Int Small Bus J 31(5):473-495

Shane S, Nicolaou N, Cherkas L, Spector TD (2010) Genetics, the Big Five, and the tendency to be selfemployed. J Appl Psychol 95(6):1154-1162

Skriabikova OJ, Dohmen T, Kriechel B (2014) New evidence on the relationship between risk attitudes and self-employment. Labour Econ 30:176-184

Sohn K (2017) The risk preferences of entrepreneurs in Indonesia. Bull Econ Res 69(3):271-287

Staniewski MW, Janowski K, Awruk K (2016) Entrepreneurial personality dispositions and selected indicators of company functioning. J Bus Res 69(5):1939-1943

Stel Av, Carree M, Thurik R (2005) The effect of entrepreneurial activity on national economic growth. Small Bus Econ 24(3):311-321

Stewart WH, Roth PL (2001) Risk propensity differences between entrepreneurs and managers: a metaanalytic review. J Appl Psychol 86(1):145-153

Stewart WH, Roth PL (2004) Data quality affects meta-analytic conclusions: a response to Miner and Raju (2004) concerning entrepreneurial risk propensity. J Appl Psychol 89(1):14-21

Stewart WH, Roth PL (2007) A meta-analysis of achievement motivation differences between entrepreneurs and managers. J Small Bus Manag 45(4):401-421

Stewart WH, Watson WE, Carland JC, Carland JW (1999) A proclivity for entrepreneurship: a comparison of entrepreneurs, small business owners, and corporate managers. J Bus Ventur 14(2):189-214

Strobl A, Matzler K, Nketia BA, Veider V (2018) Individual innovation behavior and firm-level exploration and exploitation: how family firms make the most of their managers. Rev Manag Sci 14:809-844

Strudler Wallston B, Wallston KA (1978) Locus of control and health: a review of the literature. Health Educ Monogr 6(1):107-117 
Suárez-Álvarez J, Pedrosa I, García-Cueto E, Muñiz J (2016) Locus of control revisited: development of a new bi-dimensional measure. Anales de Psicologia 32:578-586

Taormina R, Lao S (2007) Measuring Chinese entrepreneurial motivation: personality and environmental influences. Int J Entrep Behav Res 13:200-221

Tranfield D, Denyer D, Smart P (2003) Towards a methodology for developing evidence-informed management knowledge by means of systematic review. Br J Manag 14(3):207-222

Utsch A, Rauch A, Rothfuss R, Frese M (1999) Who becomes a small scale entrepreneur in a post-socialist environment: on the differences between entrepreneurs and managers in East Germany. EMBO J 37:31-42

Voda AI, Florea N (2019) Impact of personality traits and entrepreneurship education on entrepreneurial intentions of business and engineering students. Sustainability 11:1192

Wallston KA, Wallston BS, DeVellis R (1978) Development of the multidimensional health locus of control (MHLC) scales. Health Educ Monogr 6(2):160-170

Ward EA (1997) Multidimensionality of achievement motivation among employed adults. J Soc Psychol 137(4):542-544

Wickham P (2006) Strategic entrepreneuship. Pearson Education Limited, UK

Wilson F, Kickul J, Marlino D (2007) Gender, entrepreneurial self-efficacy, and entrepreneurial career intentions: implications for entrepreneurship education. Entrep Theory Pract 31(3):387-406

Wooten KC, Timmerman TA, Folger R (1999) The use of personality and the five-factor model to predict new business ventures: from outplacement to start-up. J Vocat Behav 54(1):82-101

Yang J, Ai D (2019) Effect of the BIG FIVE personality traits on entrepreneurial probability: influence of China's household registration system. J Lab Res 40(4):487-503

Yang MM, Li T, Wang Y (2020) What explains the degree of internationalization of early-stage entrepreneurial firms? A multilevel study on the joint effects of entrepreneurial self-efficacy, opportunitymotivated entrepreneurship, and home-country institutions. J World Bus 55(6):101114

Zeffane R (2013) Need for achievement, personality and entrepreneurial potential: a study of young adults in the United Arab Emirates. J Enterp CULT 21:75-105

Zellweger T, Sieger P, Halter F (2011) Should I stay or should I go? Career choice intentions of students with family business background. J Bus Ventur 26(5):521-536

Zhao H, Seibert SE (2006) The Big Five personality dimensions and entrepreneurial status: a meta-analytical review. J Appl Psychol 91(2):259-271

Zhao H, Seibert SE, Lumpkin GT (2010) The relationship of personality to entrepreneurial intentions and performance: a meta-analytic review. J Manag 36(2):381-404

Zimmerman BJ (2000) Self-efficacy: an essential motive to learn. Contemp Educ Psychol 25(1):82-91

Publisher's Note Springer Nature remains neutral with regard to jurisdictional claims in published maps and institutional affiliations. 